\title{
Review \\ Synthesis of Conjugated Dienes in Natural Compounds
}

\author{
Geoffrey Dumonteil (D) and Sabine Berteina-Raboin *(D)
}

check for

updates

Citation: Dumonteil, G.;

Berteina-Raboin, S. Synthesis of

Conjugated Dienes in Natural

Compounds. Catalysts 2022, 12, 86.

https://doi.org/10.3390/catal

12010086

Academic Editor: Hiroto Yoshida

Received: 14 December 2021

Accepted: 11 January 2022

Published: 13 January 2022

Publisher's Note: MDPI stays neutral with regard to jurisdictional claims in published maps and institutional affiliations.

Copyright: (C) 2022 by the authors Licensee MDPI, Basel, Switzerland. This article is an open access article distributed under the terms and conditions of the Creative Commons Attribution (CC BY) license (https:// creativecommons.org/licenses/by/ $4.0 /)$.
Institute of Organic and Analytical Chemistry (ICOA), University of Orleans, UMR-CNRS 7311, BP 6759, Rue de Chartres, 45067 Orleans, France; Geoffrey.Dumonteil@euroapi.com

* Correspondence: sabine.berteina-raboin@univ-orleans.fr

Abstract: This review describes the various synthetic methods commonly used to obtain molecules possessing conjugated dienes. We focus on methods involving cross-coupling reactions using various metals such as nickel, palladium, ruthenium, cobalt, cobalt/zinc, manganese, zirconium, or iron, mainly through examples that aimed to access natural molecules or their analogues. Among the natural molecules covered in this review, we discuss the total synthesis of a phytohormone, Acid Abscisic (ABA), carried out by our team involving the development of a conjugated diene chain.

Keywords: diene compounds; cross-coupling reactions; Mizoroki-Heck; natural products; abscisic acid

\section{Introduction}

Conjugated dienes or, more generally, polyenic scaffolds are present in many biologically interesting natural molecules (Figure 1) [1,2]. Developing new approaches to design these structures is therefore of great synthetic interest. The olefination reaction is often associated with the uncontrolled production of $\mathrm{E}$ and $\mathrm{Z}$ isomers, which may require careful purification [3]. Currently, a large number of reactions can be used to obtain this motif, in particular cross-coupling reactions $[4,5]$. This review will focus on these coupling reactions using various metals.<smiles>CCOC(=O)c1ccccc1</smiles>

Modiolin<smiles>CC1=CC(=O)CC(C)(C)[C@@]1(O)/C=C/C(C)=C\C(=O)O</smiles>

Abscisic acid<smiles>COC(C/C=C/C=C(\C)C(=O)O)CC/C=C/CCCC(C)O</smiles>

Dolatrienic acid<smiles>CC(/C=C/C(=O)NO)=C\C(C)C(=O)c1ccc(N(C)C)cc1</smiles>

Trichostatin A
Figure 1. Examples of natural products containing a conjugated diene moiety.

\section{Coupling Reactions}

\subsection{Homocoupling Reactions}

Generally, homocoupling is a side reaction of a cross coupling between two chemical species catalyzed by a metal and is not used for the synthesis of natural molecules. However, it is possible to promote this type of coupling with some metals or even by reacting only 
one reagent to be coupled and can be useful for generating intermediate reactants for the more complex synthesis of interesting molecules depending on the starting material.

Conjugated dienes can be obtained by homocoupling reactions. Cahiez's team recently developed two homocoupling conditions from organomagnesium derivatives [4]. Their first condition used iron (III) chloride as the catalyst. This method proved to be very effective on aryl compounds (Table 1, entries 1 and 2) and showed interesting activity on alkene compounds. In fact, the homocoupling of (E)-styrylmagnesium bromide on itself mainly led to the compound (E/E), with a yield of $68 \%$ (Table 1, entry 4 ).

Table 1. Homocoupling of organomagnesium compounds in the presence of $\mathrm{FeCl}_{3}$.

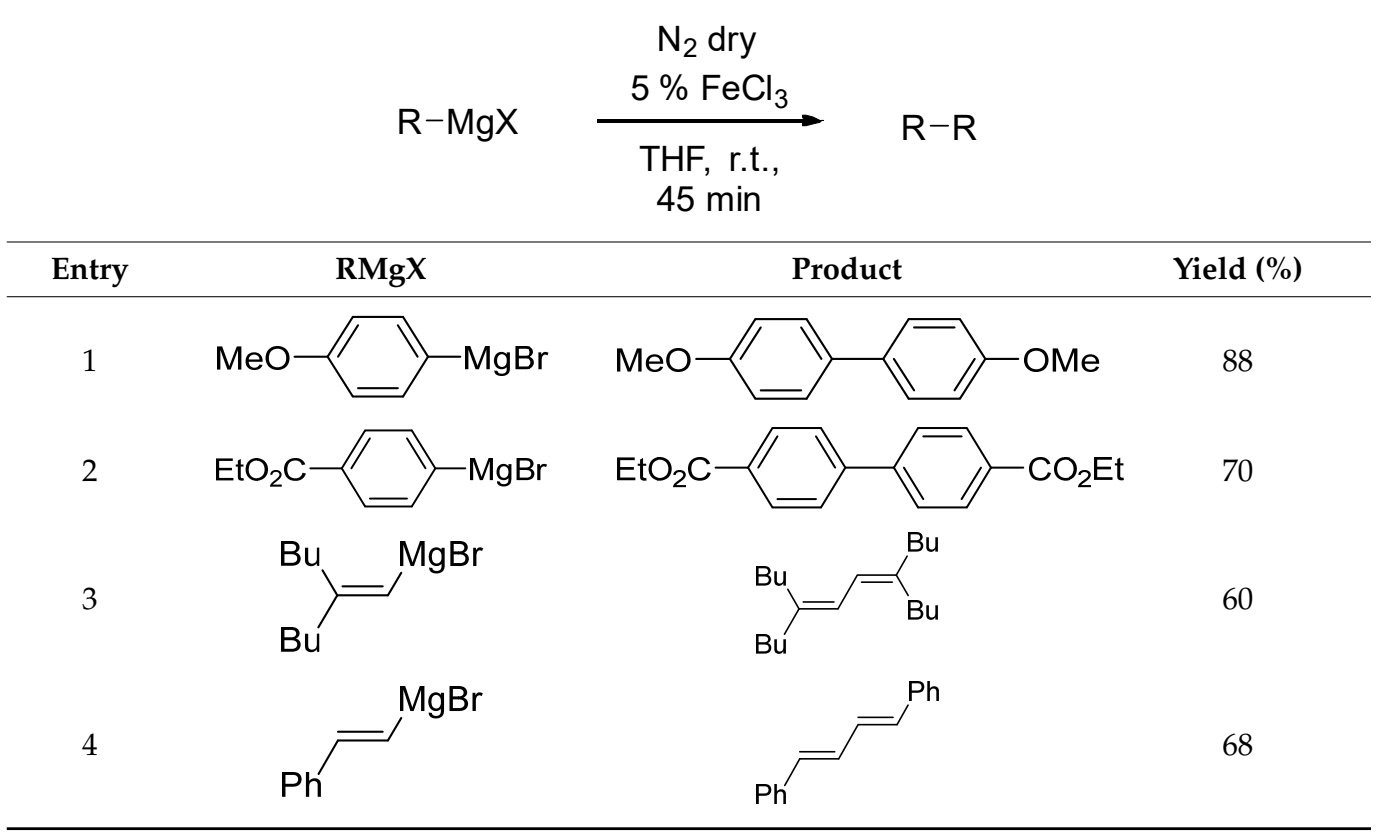

This method is efficient for homocoupling between $\mathrm{sp}^{2}$ carbons but is inefficient on sp carbons. Cahiez's team then set up a second methodology using a manganese derivative: manganese (II) chloride [4], since it turned out that these compounds had similar behavior to the coupling of organomagnesium compounds. The conditions of the previous homocoupling were applied with manganese and led to very good results. Upon applying this method to the aryl compound, better yields were obtained (Table 2, entries 1 and 2). This trend was confirmed on the diene compounds, with an increase in yield of nearly $30 \%$ on the di-butyl compound (Table 2 , entry 3 versus Table 1 , entry 3 ). It is interesting to note that this homocoupling reaction preserved the $\mathrm{Z}$ or $\mathrm{E}$ configuration of the starting organomagnesium compounds since after the reaction, the main compound that was obtained corresponded to the conjugated diene of the $(E / E)$ or $(Z / Z)$ configuration (Table 2, entries 4 and 5). This method was extended to the synthesis of alkyne compounds, and various products were obtained with very good yields (Table 2, entries 5 and 6). These conjugated dienes can be advantageously reduced to conjugated dienes. 
Table 2. Homocoupling of organomagnesium compounds in the presence of $\mathrm{MnCl}_{2}$.

$\frac{5 \% \mathrm{MnCl}_{2} \cdot 2 \mathrm{LiCl}}{\mathrm{THF} \text { r.t., }}$
$45 \mathrm{~min}$

\subsection{Metal Catalyzed Reactions}

\subsubsection{Reactions Catalyzed by Ruthenium}

\section{Metathesis}

Metathesis, a coupling reaction between two vinyl units, is catalyzed by a metal complex, such as Grubbs or Schrock catalysts [4,6-8]. This "Ring-Closing Metathesis" reaction makes it possible to form 1,3-diene compounds. Several teams have developed methods to obtain 1,3-diene compounds and have been more or less successful. During the last decade, however, Fürstner's team developed an efficient method to generate conjugated diene compounds with stereoselectivity control [9].

First, they observed the low selectivity of the $(\mathrm{E}, \mathrm{Z})$ isomer towards the other two possible isomers through the use of the first-generation Grubbs catalyst. In addition, they observed a parasitic ring contraction reaction, which resulted in a single alkene 3 (Table 3).

Table 3. Metathesis by ring closure with the 1st generation Grubbs catalyst.

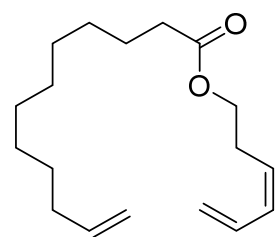

1
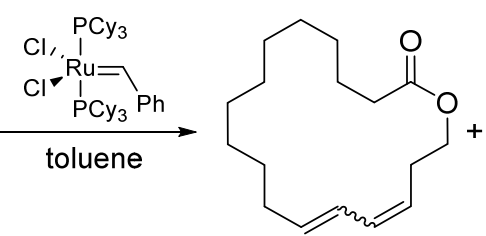

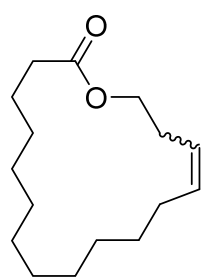

3

\begin{tabular}{cccccc}
\hline Entry & Catalyst & Temperature $\left({ }^{\circ} \mathbf{C}\right)$ & $\mathbf{t}(\mathbf{h})$ & $\mathbf{2}(\mathbf{d r})$ & $\mathbf{3}$ (dr) \\
\hline 1 & Grubbs I & 20 & 24 & $86 \%(3: 1: 1)$ & $14 \%(5: 1)$ \\
2 & Grubbs I & 110 & 22 & $91 \%(2.7: 1: 1)$ & $9 \%(5: 1)$ \\
3 & Grubbs II & 20 & 24 & $<5 \%$ & $95 \%(7: 1)$ \\
4 & Grubbs II & 110 & 22 & $12 \%(1: 3: 4)$ & $88 \%(6: 1)$ \\
\hline
\end{tabular}


Using the first-generation catalyst at $20{ }^{\circ} \mathrm{C}$, compound 2 was formed in yields of up to $86 \%$, but the expected compound $\mathrm{E}, \mathrm{Z}$ was mixed with minor by-products (Table 3, entry 1). By increasing the temperature to $110{ }^{\circ} \mathrm{C}$, and in the presence of $\mathrm{Cy}_{3} \mathrm{P}(\mathrm{O})$, the yield was slightly improved but to the detriment of compound (E,Z), which decreased compared to the other compounds (Table 3, entry 2). Interestingly, the use of the second-generation Grubbs catalyst promoted cycle contraction at the expense of compound 2 (entries 3 and 4).

In view of this selectivity problem, Fürstner's team proposed the use of a silyl group on the diene in order to promote ring closure in favor of the compound (E,Z) (Scheme 1).

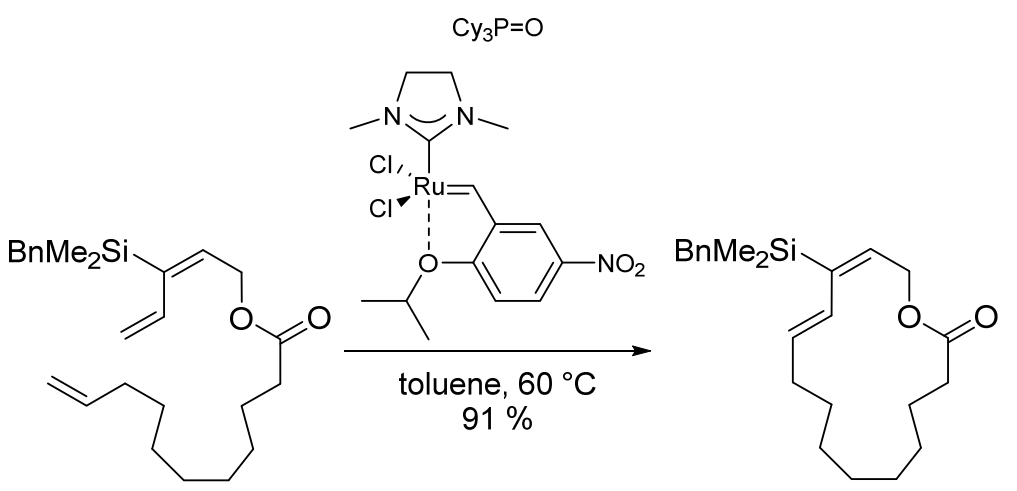

Scheme 1. Conditions of metathesis cyclization favoring the compound E, Z.

With this approach, a lactimidomycin synthetic pathway was established (Scheme 2) using compound 4 in the reaction described above, leading to compound 5 in a $76 \%$ yield. Lactidomycin is a macrolide antibiotic that is a potent inhibitor of cell proliferation or cell migration and also demonstrates antifungal properties [10].
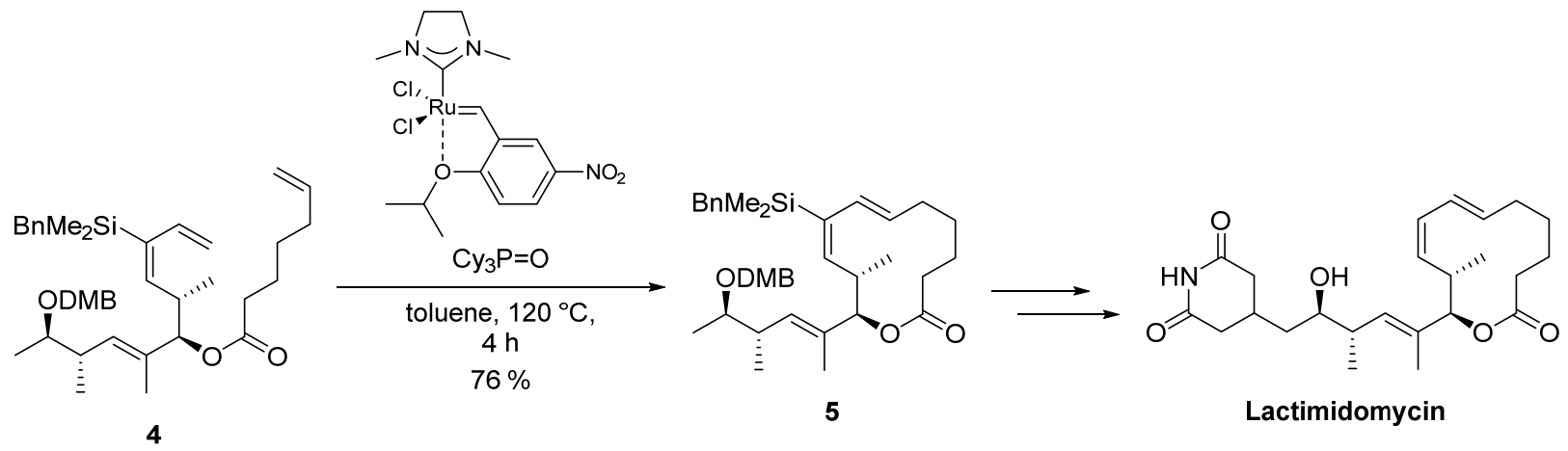

Scheme 2. Synthesis of lactimidomycin by metathesis.

Silylated compounds are readily available via the nucleophilic substitution of the chlorine atom of an alkylsilyl chloride derivative with an alkyne that has been previously deprotonated at $-78{ }^{\circ} \mathrm{C}$ in THF and that has been allowed to obtain the desired compound. In the present case, the compound has an alcohol function protected by the action of 2,3-dihydro-2H-pyrane. Subsequently, the alkyne function was protected by benzyldimethylsilyl chloride. The alcohol was deprotected using hydrochloric acid. The triple bond was selectively reduced to the trans compound, which was iodinated and used in a Stille coupling reaction with tributyl (vinyl) tin. Under these conditions, the compound that was obtained is a conjugated diene with a silyl group in position 3 (Scheme 3 ). 


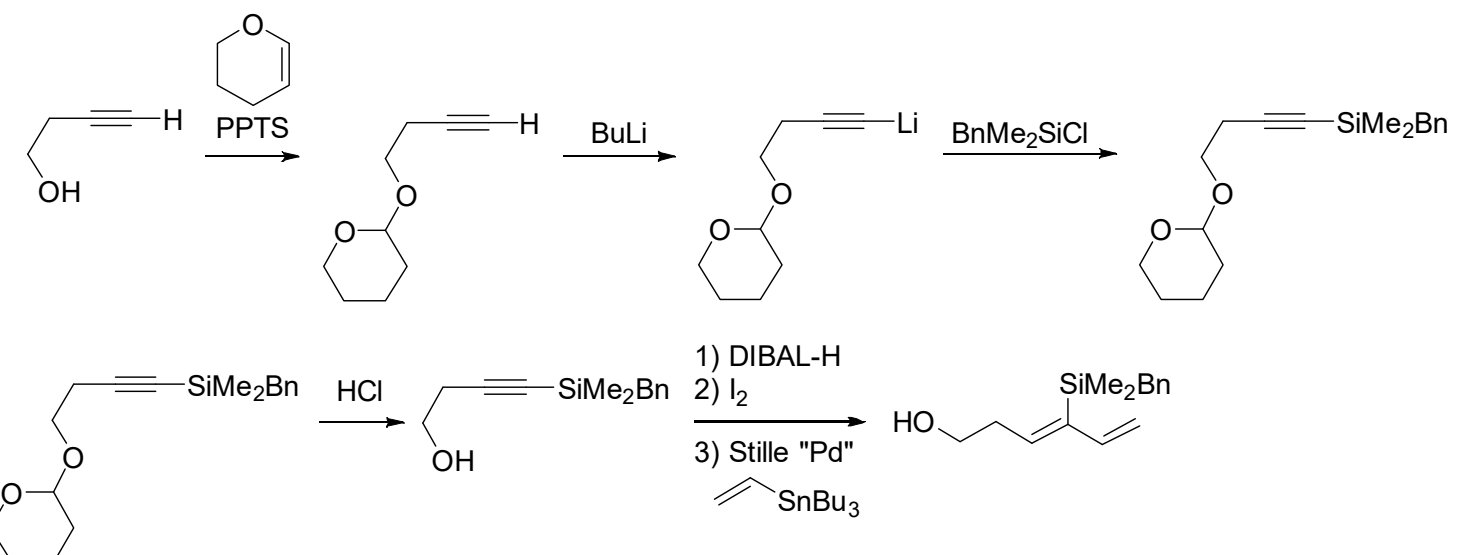

Scheme 3. Synthesis of a silylated derivative.

Enyne Metathesis

Ring-closing enyne metathesis (RCEYM) is C-C bond formation that leads to 1,3-diene via two possible mechanisms: metal salt catalyzed enyne bond reorganization and carbenemediated enyne metathesis [11]. This reaction can be intra or intermolecular and is favored by transition metals such as molybdenum or tungsten and more frequently by ruthenium (Schemes 4 and 5).
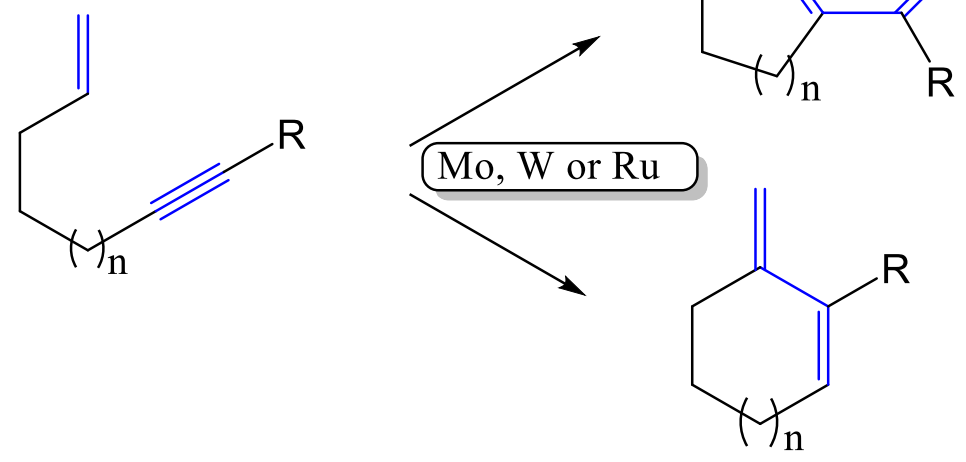

Scheme 4. Intramolecular RCEYM.<smiles>[R]C#C[I-]/C=C\C[R]</smiles>

Scheme 5. Intermolecular RCEYM.

Access to a family of polycyclic $\beta$-lactams 8 has been described by Genêt et al. [12] and involves the RCEYM reaction followed by Diels-Alder final cyclization, producing annulated $\beta$-lactams compounds with an interesting antibacterial activity (Scheme 6). 

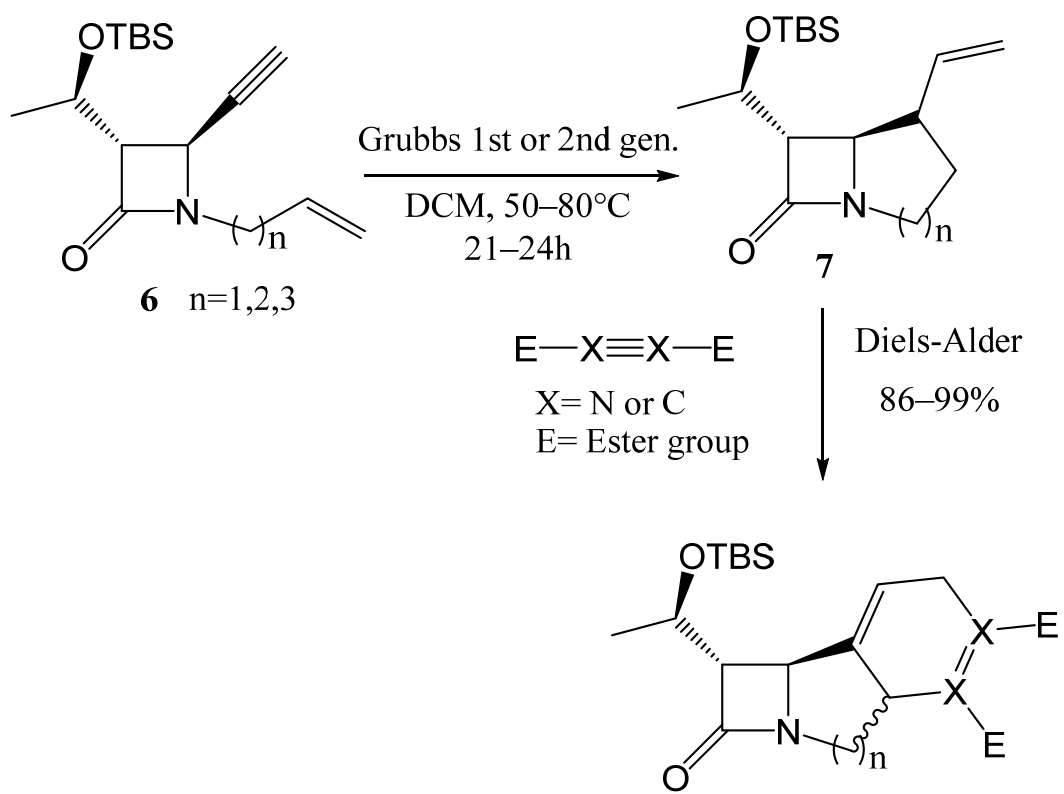

8

Scheme 6. Annulated $\beta$-Lactams synthesis by RCEYM followed by Diels-Alder.

Sato's group used ynamides and ethylene [13]. For this coupling, the amine must be protected by an electron withdrawing group, such as a tosyl. However, the alkyne can be substituted with various groups such as benzyl methanoate, which resulted in the coupled compound in a quantitative yield in just $2 \mathrm{~h}$ (Table 4, entry 1 ). When the ynamide was substituted by an n-butyl group, the reaction time increased considerably to $19 \mathrm{~h}$, but the yield was still very good (Table 4 , entry 2 ). When the group carried by the triple bond was a silyl ether, the yield dropped to $20 \%$ for $21 \mathrm{~h}$ of reaction time, but the starting compound was recovered in a yield of $57 \%$ (Table 4 , entry 3 ). With an ynamide terminal, the reaction did not take place, and only $45 \%$ of the starting material was recovered. The same thing occurred when the ynamide was substituted with a TMS group, but in this case, $85 \%$ of the starting material was recovered.

Table 4. Obtaining various dienes substituted by Sato.

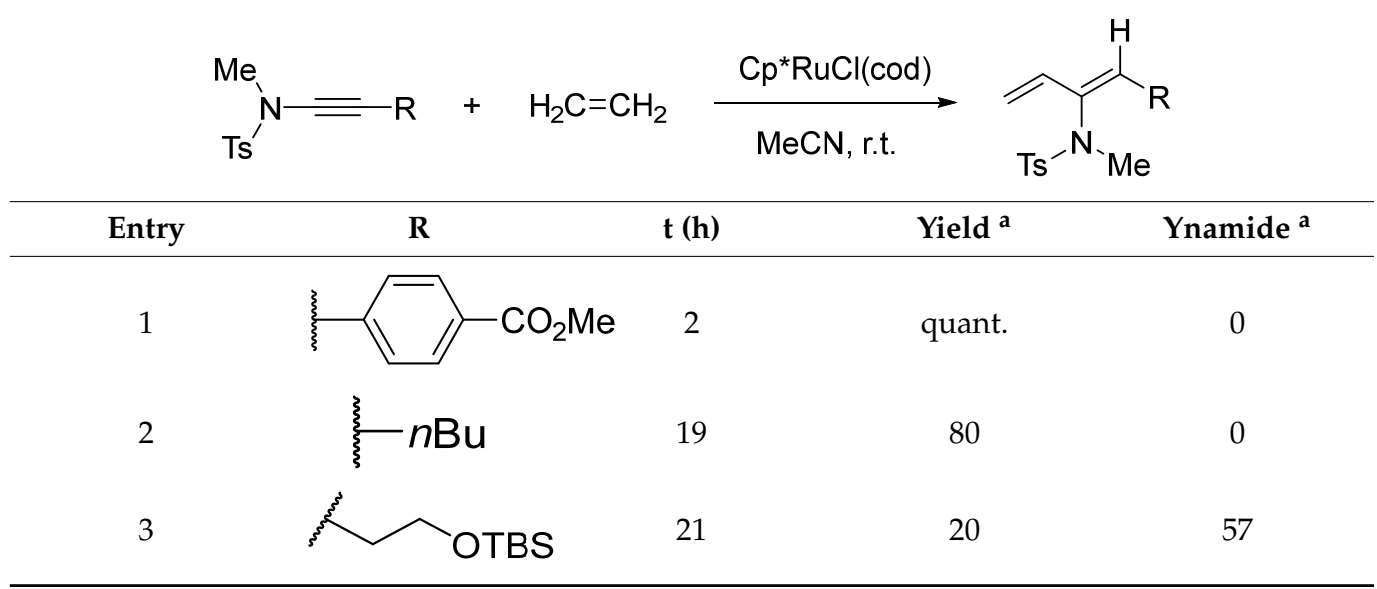


The regioselectivity of the reaction comes from the addition of the catalyst to the ynamide, to which the ethylene was coupled. This is because the three compounds formed a five-member metallo ring with nitrogen in trans compared to ruthenium. $\beta$ elimination then led to the conjugated diene compound systematically with the $Z$ stereochemistry. This stereochemistry was verified by NOE coupling on test molecule 10, which was obtained from compound 9 (Scheme 7).

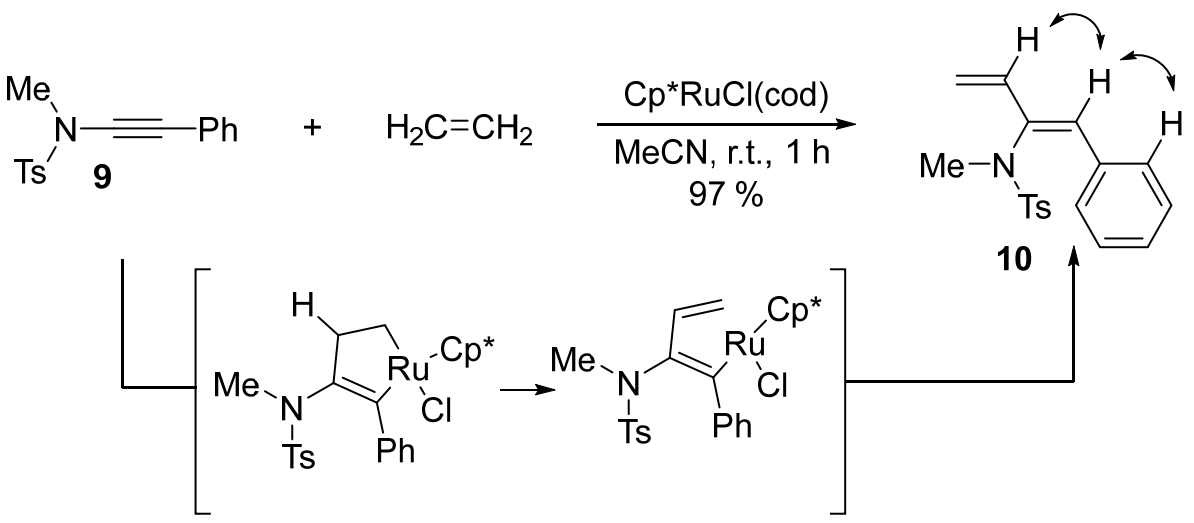

Scheme 7. Mechanism for the reaction described by Sato.

Sato and his team transposed their reaction to an oxazolidinone substituted on nitrogen by an alkyne. Various alkyne derivatives were used to obtain results that were very similar to those obtained with the ynamides (Table 5, entries 1 and 2). Nevertheless, the use of a butyl derivative was not efficient because only $10 \%$ of the coupling compound was obtained against the $80 \%$ that had been obtained previously (Table 5, entry 3 ).

Table 5. Coupling to oxazolidinone.
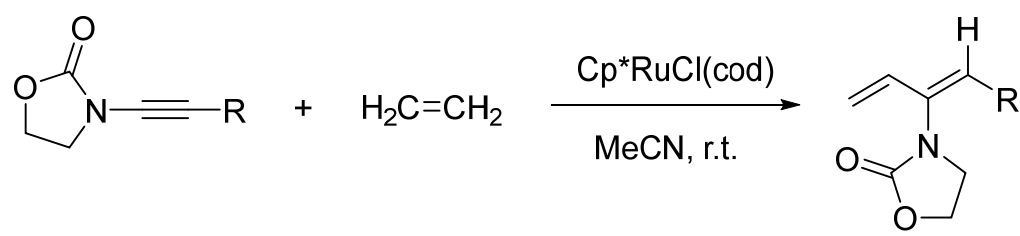

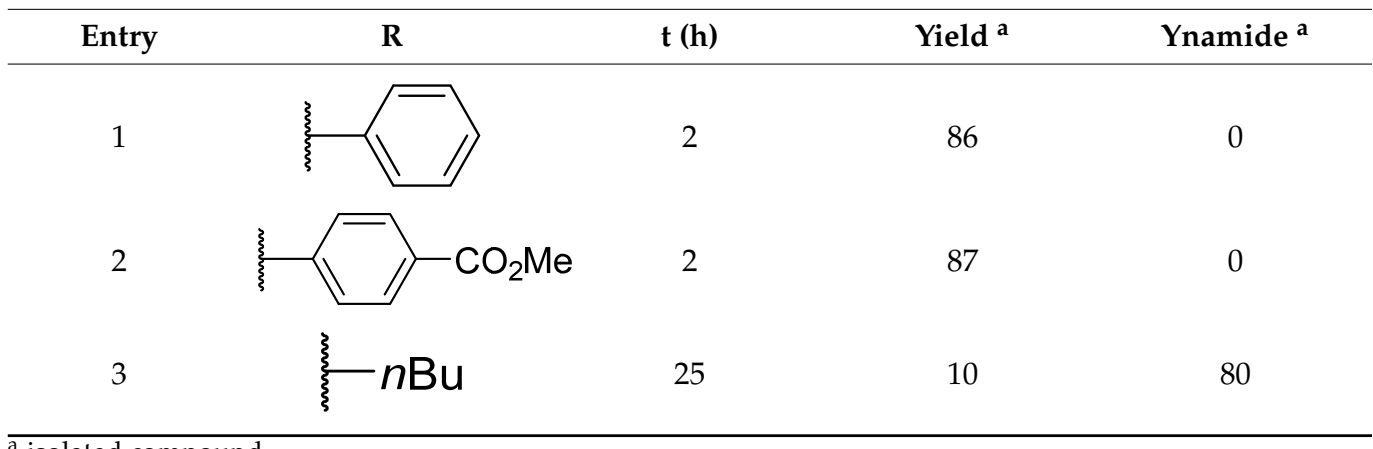

a isolated compound.

In 2014, Zhao's group developed a coupling from diphenylethyne and acrylate derivatives in toluene at room temperature [14]. They obtained conjugated diene compounds with an (E,Z) configuration. Different esters were used with very good yields. For example, the use of methyl or ethyl acrylate allowed them to obtain coupling products with yields of $98 \%$ and $99 \%$, respectively (Table 6, entries 1 and 2 ). The yield remained excellent when the ester was an isomer of butane, such as tert or $n$-butyl (Table 6 , entries 3 and 4 ). 
Table 6. Alkyne-acrylate coupling according to Zhao's group.

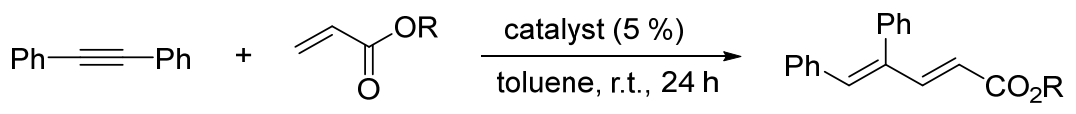

\begin{tabular}{ccc} 
& \\
\hline Entry & Yield (\%) \\
\hline 1 & $\mathbf{R}$ & 98 \\
3 & $\mathrm{Me}$ & 99 \\
4 & $\mathrm{Et}$ & 98 \\
& $n \mathrm{Bu}$ & 90 \\
\hline
\end{tabular}

This efficient method was generalized to a large number of alkynes, as phenyls were not necessary to ensure the success of the reaction. Various substituents of the alkyne led to the desired alkenes (Scheme 8).

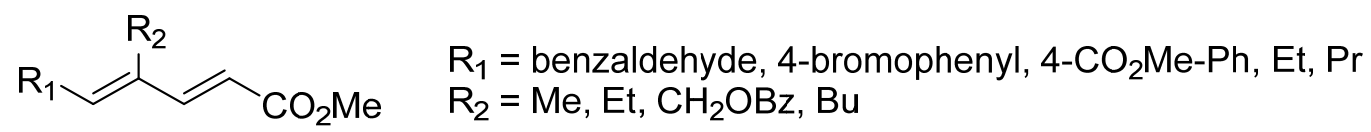

Scheme 8. Generalization of the method by Zhao's group.

An application of an intermolecular enyne metathesis followed by a diene cross metathesis was used as the key steps in the total synthesis of (-)-amphidinolide E described by Lee et al. [15]. This compound is a part of natural macrolides family and possesses a high cytotoxicity against various cancer cell lines. They successfully used the second generation of the Grubbs catalyst to generate diene 12 and then the required triene 13 using a cross-metathesis step. Subsequent standard modifications led to the expected (-)amphidinolide E (Scheme 9).

\subsubsection{Example of Analog Cobalt Catalyzed Coupling}

In 2010, Cheng's group developed a reaction to obtain 1,3-diene derivatives from vinyl compounds in the presence of a cobalt catalyst [16]. When the diphenylethyne was placed in the presence of styrene, the diene was obtained at a $97 \%$ yield (Table 7 , entry 1 ). The reaction was also effective with para bromostyrene (Table 7, entry 2) or with the use of donor groups in the meta position of styrene, which led to the corresponding products in very good yields (Table 7, entries 3 to 5). When trimethylsilylethylene was used, the coupling took place, but moderately, even when the reaction time was increased to $36 \mathrm{~h}$ (Table 7, entry 6). 


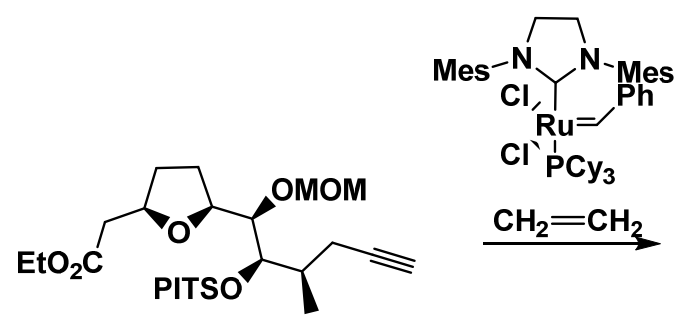

11

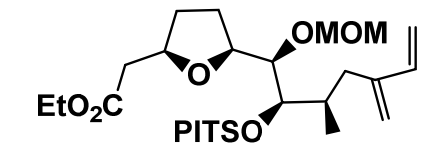

12
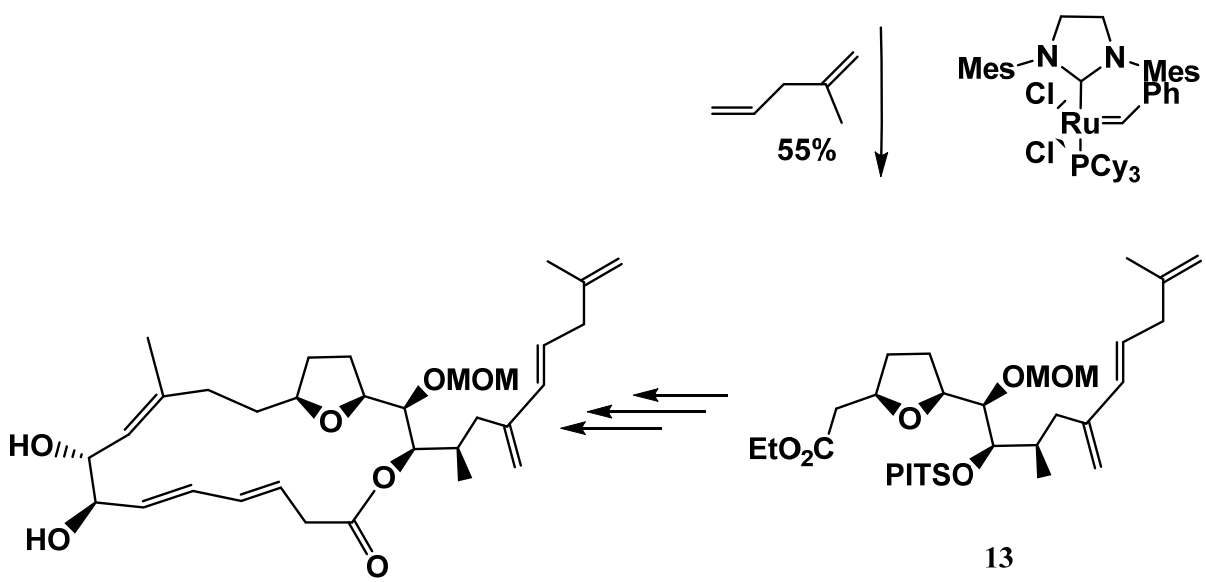

(-)-amphidinolide E

Scheme 9. Synthesis of (-)-amphidinolide E via an intermolecular enyne metathesis.

Table 7. Cheng et al.'s cobalt coupling.

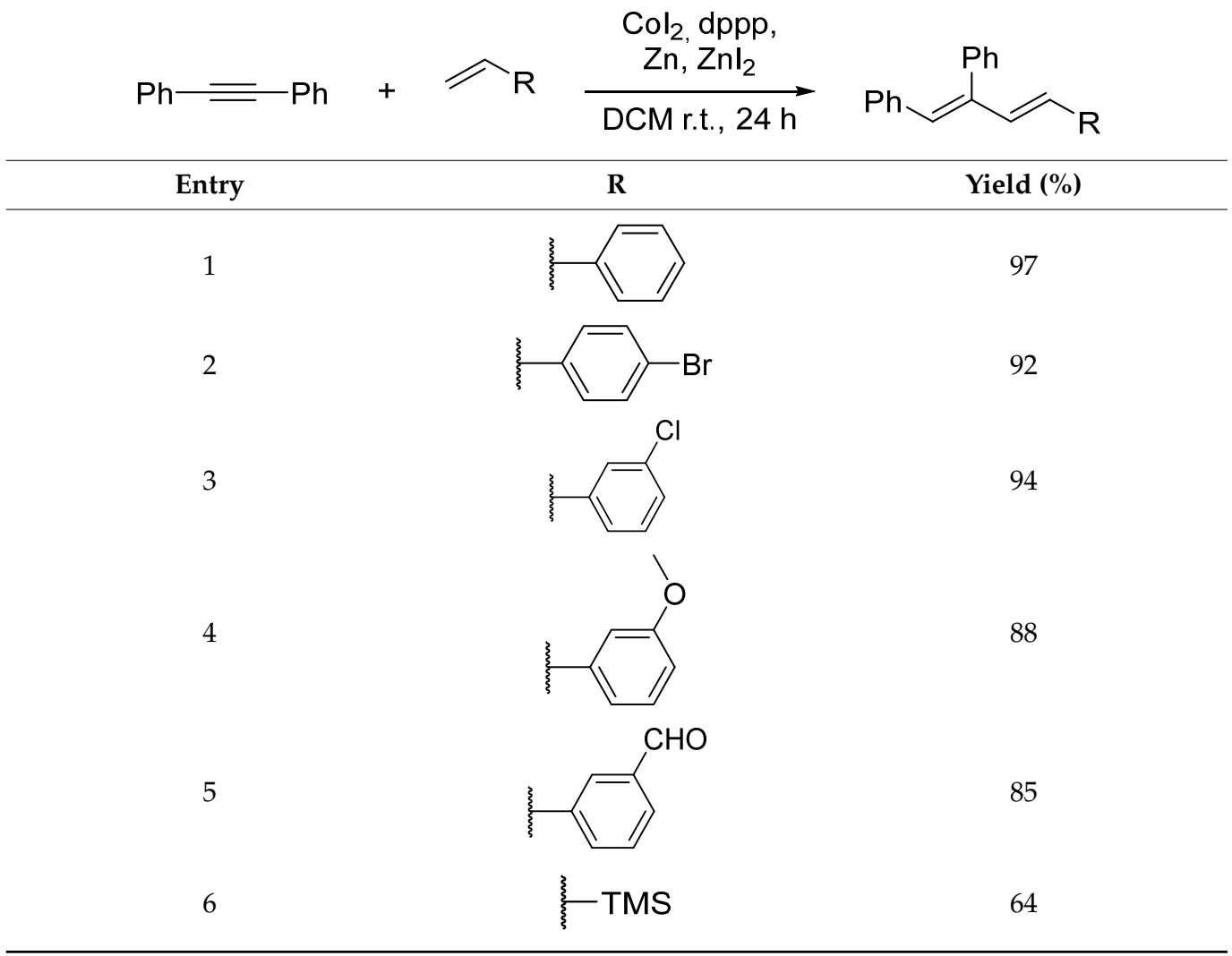


After varying the vinyl compound, Cheng et al. used different alkyne compounds in the presence of styrene, such as 3-pentynylthiophene or 4-phenylbut-3-yn-1-ol. However, with $\mathrm{CoI}_{2}$, dppp, (1,3-bis (diphenylphosphino) propane), the coupling compounds were not obtained. Cheng opted for a catalyst with a lower steric hindrance due to its ethane and non-propane ligand $\left(\mathrm{Co}(\mathrm{dppe}) \mathrm{Br}_{2}\right)$ as well as the presence of bromine atoms that were smaller than iodine atoms. Under these conditions, the coupling products were successfully obtained, with yields of $75 \%$ and $91 \%$, respectively (Scheme 10).

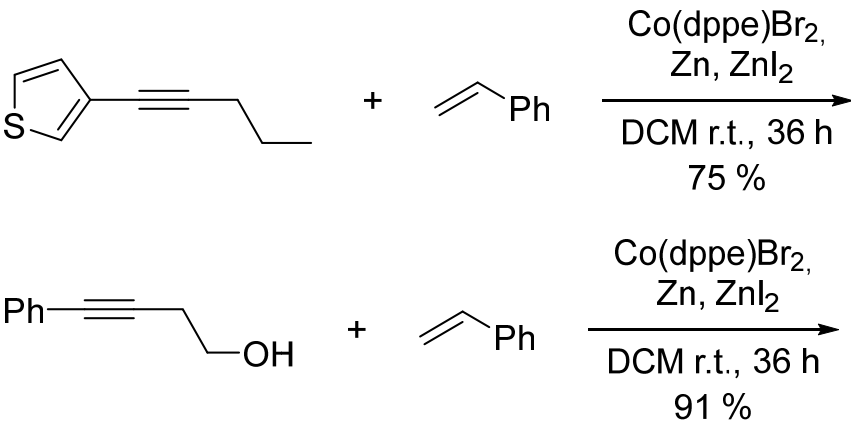<smiles>CCCC(C=Cc1ccsc1)=Cc1ccccc1</smiles>

Scheme 10. Extension of cobalt coupling according to Cheng.

\subsubsection{The Stille Reaction}

The Stille reaction, a palladium-catalyzed cross-coupling reaction between an organostannane and a halide, was first described by Stille in 1985 [17] and was illustrated through numerous examples. Herein, we will focus on those that led to conjugated dienes. The coupling between the (E)-(iodovinyl) benzene and a stannyl derivative successfully resulted in the corresponding 1,3-diene compound. It is important to note that the reaction exclusively kept the stereochemistry of the reactants involved. This reaction is of great synthetic interest because a compound with a trans stereochemistry will lead to a trans diene (Scheme 11) [18,19].
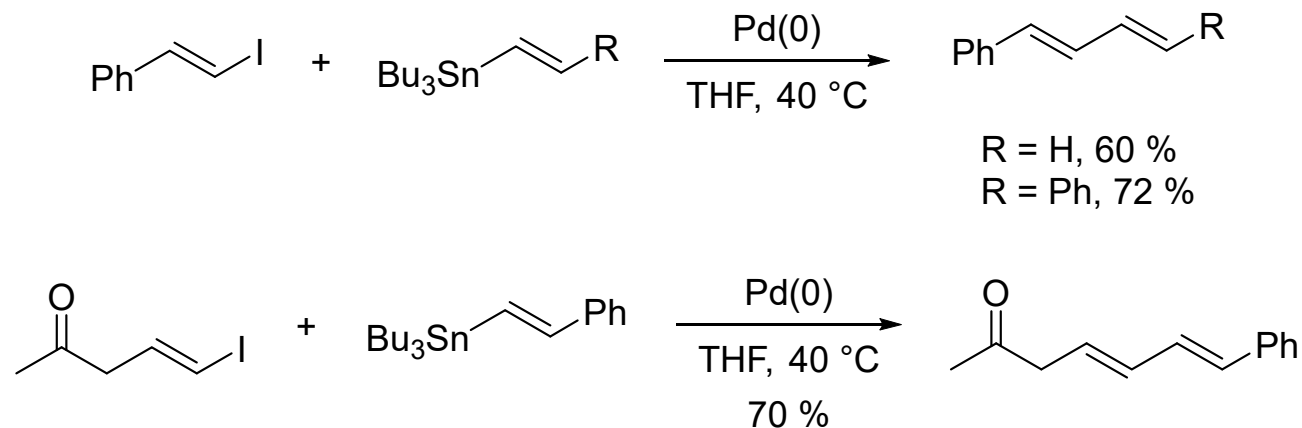

Scheme 11. Stille coupling to generate conjugated dienes.

In 2001, Pattenden's team proposed the total synthesis of natural molecules comprising a conjugated diene moiety via the Stille coupling reaction [20]. Their work began with the application of Farina's conditions, i.e., the use of palladium tetrakistriphenylarsine in THF at reflux, which enabled them to obtain compound 15 via the intramolecular cyclization of compound 14 at a $37 \%$ yield (Scheme 12) [21]. 
<smiles>CCC(C)[Sn]/C=C/C(OC)C(/C=C(\C)CCCCC(=O)NC(C)c1nc(/C=C\Br)cs1)O[Sb](C)(C)C</smiles>

14

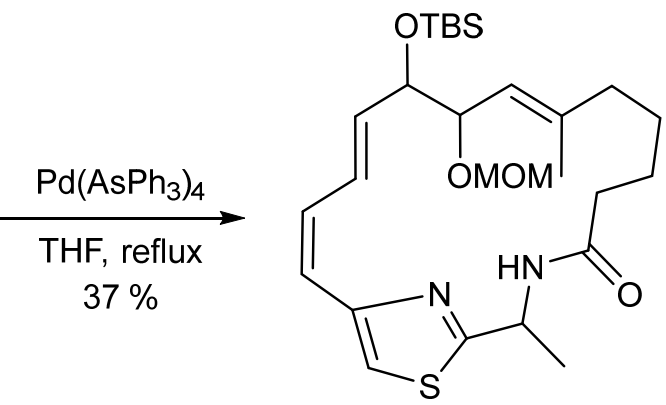

15

Scheme 12. Intramolecular cyclization by Stille coupling.

Several years later, Morris' group attempted to obtain hydroxystrobilurin A (methyl (2E,3Z,5E)-3-(hydroxymethyl)-2-(methoxymethylidene)-6-phenylhexa-3,5-dienoate), with Stille coupling as a key reaction [22]. Hydroxystrobilurin A has the same biological activity of other strobilurins or oudemansins. It exhibits antifungal activities but no antibacterial activity compared to strobilurin [23]. Compound 16 was coupled with the iodine derivative 17 in the presence of $\mathrm{Pd}(\mathrm{dppf}) \mathrm{Cl}_{2}$ in anhydrous DMF. Compound 18, which is a conjugated diene, was obtained at a yield of $66 \%$. The coupling turned out to be selective at the iodine level as expected, leaving the possibility of carrying out another coupling on the bromine atom. This is, moreover, the continuation of the strategy envisaged by this team (Scheme 13).

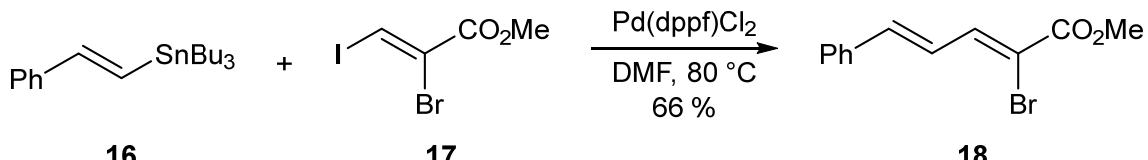

16

17

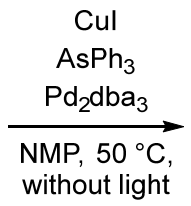

19<smiles>COC=C(C(=O)OC)C(=CC=Cc1ccccc1)COC</smiles>

20<smiles>COC=C(C(=O)OC)C(=CC=Cc1ccccc1)COC</smiles>

20

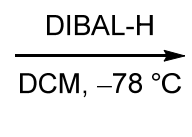

Scheme 13. Total synthesis of hydroxystrobilurin A by the Morris group.

Compound 18 was coupled with compound 19 in the presence of CuI, triphenylarsine and $\mathrm{Pd}_{2} \mathrm{dba}_{3}$ in $\mathrm{N}$-methylpyrolidine at $50{ }^{\circ} \mathrm{C}$ and was protected from light. The compound 20 thus obtained at an $86 \%$ yield was then reduced by the action of DIBAL-H on the $\alpha, \beta-$ unsaturated methyl ester. A $12 \%$ yield of hydroxystrobilurin A was thus obtained. In this case, the coupling took place on the bromine atom unlike the previous reaction. This may be due to the use of $\mathrm{CuI}$, which activates the C-Br bond by the complexation of the latter, and then via transmetalation with palladium, it initiates the catalytic cycle of the coupling. 
Stannylated compounds, although easily accessible, remain extremely toxic. Despite the effectiveness of this coupling, it is therefore necessary to consider its environmental impact during total synthesis. In addition, if this coupling is used for the synthesis of active compounds, slight traces of tin could still be present in the final formulation.

Amos B. Smith et al. [24] described the total synthesis of the Lituarines B and C macrocyclic lactones involving the formation of $(\mathrm{E} / \mathrm{Z})$-dienamide side chain with cis-vinyl stannane by the Stille coupling reaction (Scheme 14). These compounds are present in biologically active marine natural products. Cytotoxic and antineoplastic activities were observed.
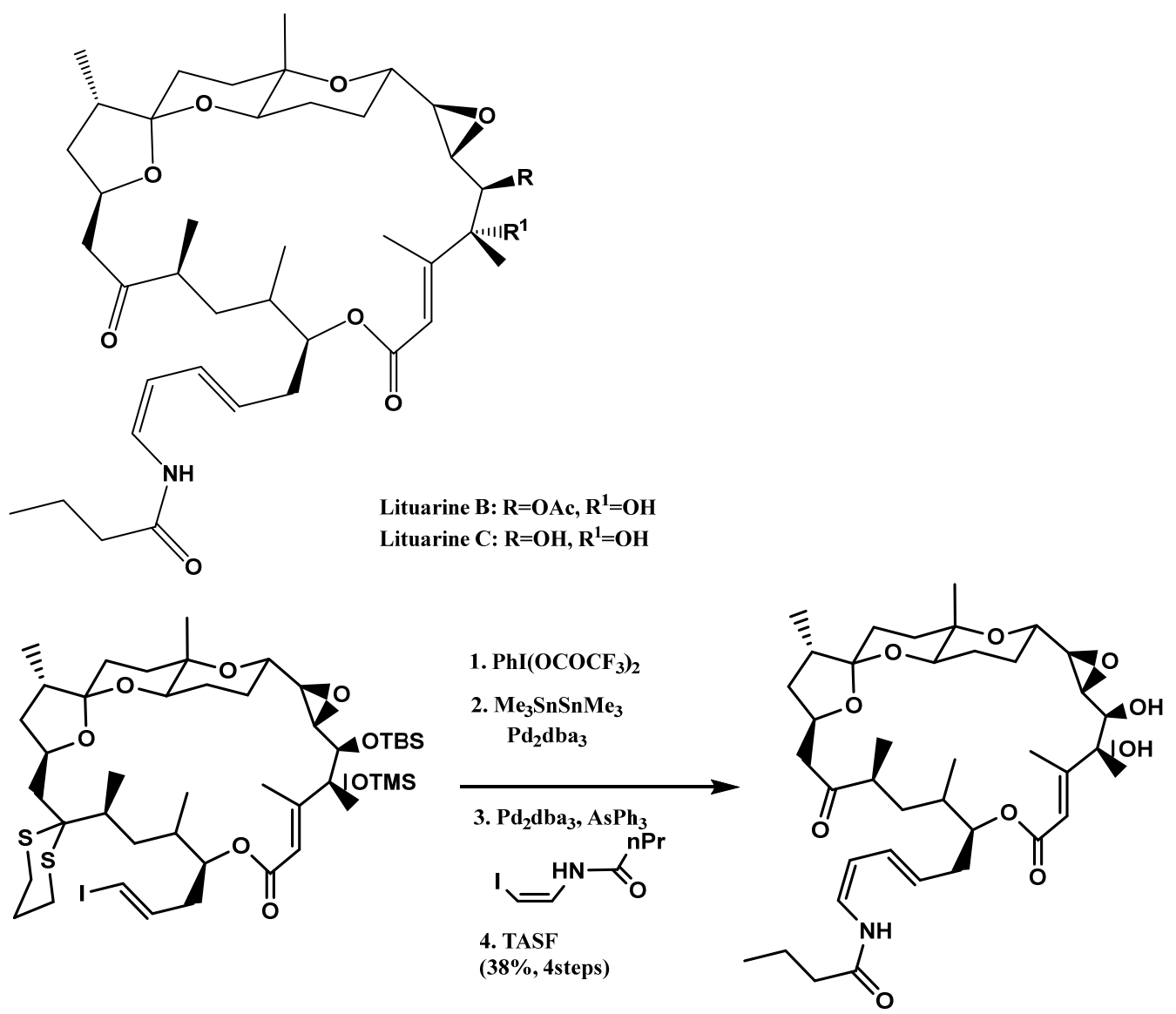

Scheme 14. Lituarines B and C and stannylation of the vinyl iodide moiety.

\subsubsection{The Suzuki-Miyaura Reaction}

In 1979, the Suzuki team [25-27] published a coupling reaction between a boronic acid derivative and a vinyl bromide in the presence of a base and palladium (Scheme 15) [28].<smiles>[GeH2]C=CB1Oc2ccccc2O1</smiles>

21

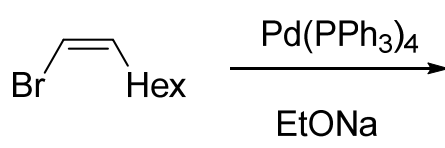

22<smiles>[Li]/C=C\C=[V]</smiles>

23<smiles>[R]C=CC=CC</smiles>

24

Scheme 15. Suzuki coupling reaction.

Historically, the first coupling was carried out between the compounds 21 and 22 in the presence of palladium tetrakistriphenylphosphine and sodium ethanoate, leading to the conjugated diene derivatives 23 and 24 in respective yields of $47 \%$ and $41 \%$. 
This reaction opened the way to numerous total syntheses, such as that described by Pattenden's group for the synthesis of (+)-curacin A in 2002 (Scheme 16) [29]. Curacin has been reported to be a potent antiproliferative cytotoxic compound for several cancers, including renal, colon, and breast cancers [30-33]. Curacin A interacts with binding sites that inhibit the microtubule polymerization involved in cell division and proliferation processes.

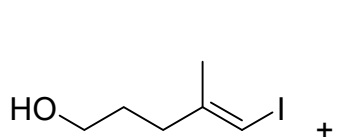

25
$(\mathrm{HO})_{2} \mathrm{~B} \curvearrowright \mathrm{OTBDMS}$
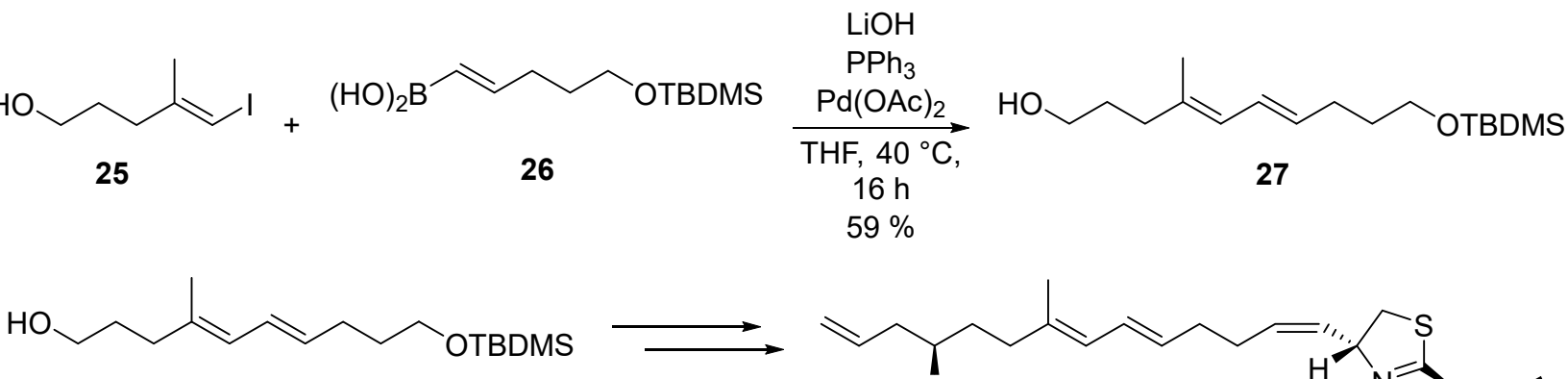

27

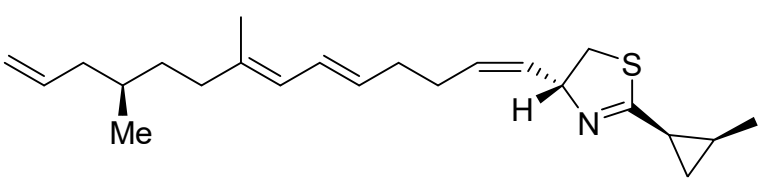

(+)-curacin A

Scheme 16. Suzuki coupling used for the synthesis of (+)-curacin A.

Compounds 25 and 26 were placed in the presence of palladium acetate, triphenylphosphine, and lithium hydroxide in degassed THF at $40{ }^{\circ} \mathrm{C}$ for $16 \mathrm{~h}$ to lead to the single isomer (E,E) of compound 27 in a $59 \%$ yield.

In 2004, Molander's group developed [34] a total synthesis of oxymidine II, which demonstrated potent antitumor activity [35] and used the Suzuki reaction as the key step for the formation of the macrocycle (Figure 2).<smiles>C/C=C\[C@H](O)[C@@H](C/C=C\NC(=O)/C=C\C=N\OC)OC(=O)c1c(O)cccc1/C=C/C=C/COC</smiles>

Figure 2. Target molecule of the Molander group.

This macrocyclization was carried out intramolecularly on molecule 21 (Scheme 17) in the presence of $\mathrm{Pd}\left(\mathrm{PPh}_{3}\right)_{4}$ derived from cesium carbonate in a THF $/ \mathrm{H}_{2} \mathrm{O}(10 / 1, v / v)$ mixture at the reflux temperature for $20 \mathrm{~h}$. Compound 30 was obtained in a $42 \%$ yield in two steps from alkyne 28. 


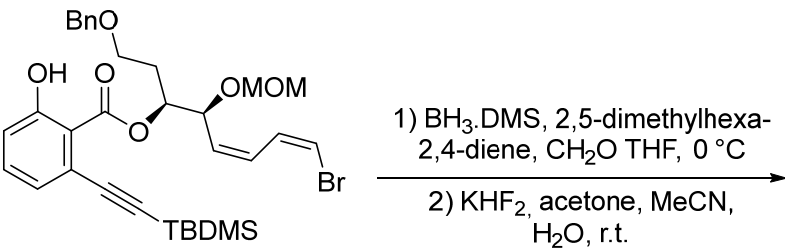

28<smiles>C/C=C\C=C/C=C/c1cccc(O)c1C(=O)O[C@@H](C/C=C\NC(=O)/C=C\C=N\OC)[C@@H](O)/C=C\C</smiles>

Oximidine II<smiles>COC(/C=C\C=C/Br)C(CCOc1ccccc1)OC(=O)c1c(O)cccc1/C=C/Br</smiles>

29

$\mathrm{Cs}_{2} \mathrm{CO}_{3}$ $\mathrm{Pd}\left(\mathrm{PPh}_{3}\right)_{4}$

$\mathrm{THF} / \mathrm{H}_{2} \mathrm{O}(10 / 1, \mathrm{v} / \mathrm{v})$,

reflux, $20 \mathrm{~h}$

$42 \%$ (2 steps)

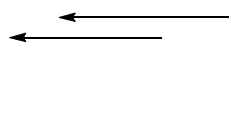<smiles>CO[C@H]1/C=C\C=C/C=C/c2cccc(O)c2C(=O)O[C@@H]1CCOCc1ccccc1</smiles>

30

Scheme 17. Suzuki coupling performed by Molander's group.

Suzuki coupling yields, among other things, conjugated diene and triene compounds from simple and easily accessible reagents. However, boronic acid derivatives comprising several chemical functions are generally expensive when they are commercially available.

\subsubsection{The Kumada-Corriu Reaction}

In 1972, both Kumada's team and Corriu's team reported the coupling reaction between an aryl halide and an organomagnesium compound in the presence of nickel as the catalyst [36,37]. In a solution in diethyl ether with a very low catalyst load, between 0.1 and $0.2 \%$, the coupled compounds were obtained in very good yields (Scheme 18).

Corriu

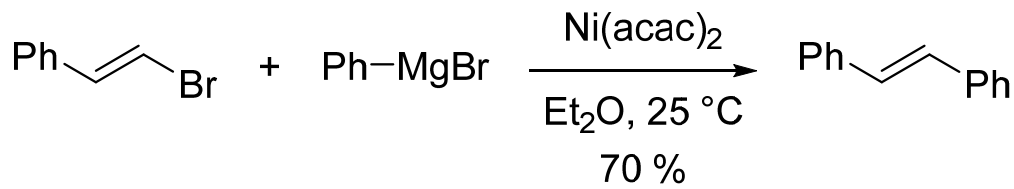

Kumada

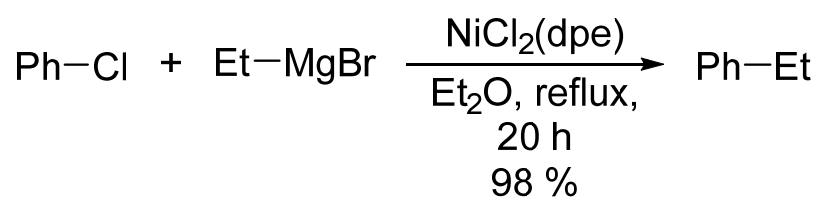

Scheme 18. Historical reactions of Kumada and Corriu.

Although initially developed with nickel, this reaction can take place in the presence of palladium. In fact, Jacobsen's group used this type of catalyst in their Kumada-Corriu reaction for the total synthesis of Ambruticin in 2001. This natural product exhibits potent antifungal activity $[38,39]$. Compound 31 was placed in the presence of palladium tetrakistriphenylphosphine and vinylmagnesium bromide in benzene under reflux to lead to conjugated diene 32 with the correct conformation. During this coupling, the stereochemistry of the compounds was preserved (Scheme 19). 
<smiles>C=C[CH+]C1O[C@H](/C(C)=C/I)CC=C1C</smiles>

31<smiles>C=C/C=C(\C)[C@@H]1CC=C(C)[C@@H](CC)O1</smiles>

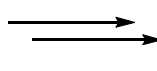

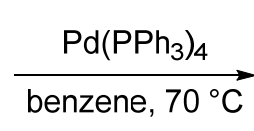

$88 \%$<smiles>C=C/C=C(\C)[C@@H]1CC=C(C)[C@@H](CC)O1</smiles>

32

Scheme 19. Total synthesis of (+)-ambruticin according to Jacobsen.

\subsubsection{The Negishi Reaction}

During the reaction developed in 1977 by Negishi, halogenated compounds were coupled with organozinc derivatives [40-42]. Historically, the first coupling was carried out between (E)-1-iodohex-1-ene and ethynylzinc chloride, which was prepared in situ by adding a solution of $\mathrm{ZnCl}_{2}$ in THF to a solution of ethynyl lithium. The reaction was carried out at room temperature in THF in the presence of $\mathrm{Pd}\left(\mathrm{PPh}_{3}\right)_{4}$ as a catalyst to yield the desired coupling compound in a yield of $83 \%$ (Scheme 20).

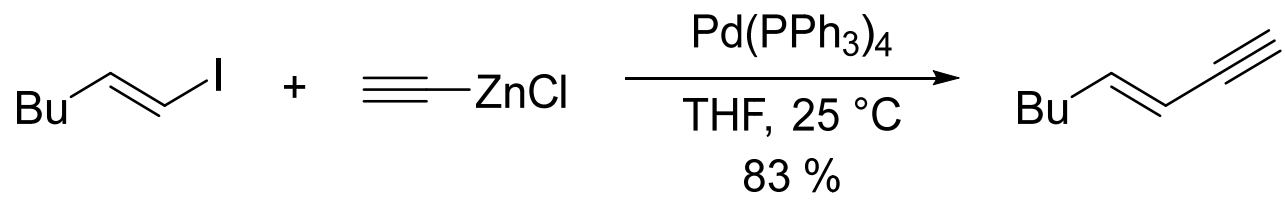

Scheme 20. Historical coupling of the Negishi reaction.

In 2008, Kershaw's team used Negishi coupling as one of the key reactions to synthesize a naturally occurring compound isolated from corals, the deoxypukalide that is obtained by the desoxygenation of pukalide [43]. The synthesis was performed from compound 33 with 2.3 equivalents of LDA to tear the acidic proton from the cycle, leading to the lithiated derivative udnergoing transmetalation in the presence of zinc chloride. The latter compound underwent Negishi coupling in the presence of compound 34 and a ferrocene palladium complex. The alcohol that was obtained was deprotected in the presence of TBAF, leading to compound 35 with a global yields of $78 \%$ in two steps. Then, various subsequent reactions led to the expected natural compound (Scheme 21).<smiles>C=C(CC[C@@H](Cc1occc1C(=C)C)C(=O)O)C(=O)O</smiles>

33<smiles>C=C[C@@H](C/C(C)=C\I)[O+]S</smiles>

34<smiles>C=C(C)[C@@H](CC)CCC1=C[C@@H](C/C(C)=C\c2cc(C(C)=O)c(C)o2)OC1=O</smiles>

1) LDA, $\mathrm{ZnCl}_{2}$ $\mathrm{PdCl}_{2} \mathrm{dppf}$

2) TBAF

$78 \%$<smiles>C=C[C@H](O)C/C(C)=C\c1cc(C(=C)OC)c(C[C@@H](CCC(=C)C(=O)O)C(=C)C)o1</smiles>

(-)-(Z)-deoxypukalide

Scheme 21. Synthesis of deoxypukalide via Negishi coupling. 
Another alternative to obtain organozinc compounds was used by Negishi during the total synthesis of vitamin A in 2001 [44]. In this case, the necessary terminal alkyne was placed in the presence of trimethylaluminum and a zirconium complex $\left(\mathrm{Cp}_{2} \mathrm{ZrCl}_{2}\right)$ in dichloromethane to generate the corresponding alkenylalane. Firstly, the trimethylaluminum and $\mathrm{Cp}_{2} \mathrm{ZrCl}_{2}$ complex chelated via a non-binding doublet of the chlorine atoms and exchanged a methyl group. Then, the triple bond on the electronic vacancy of the zirconium incorporated the methyl at the same time. The triple bond was reduced by electronic transfer. Subsequently, transmetalation took place between the zirconium and the aluminum, leading to the alkenylalane compound (Scheme 22).

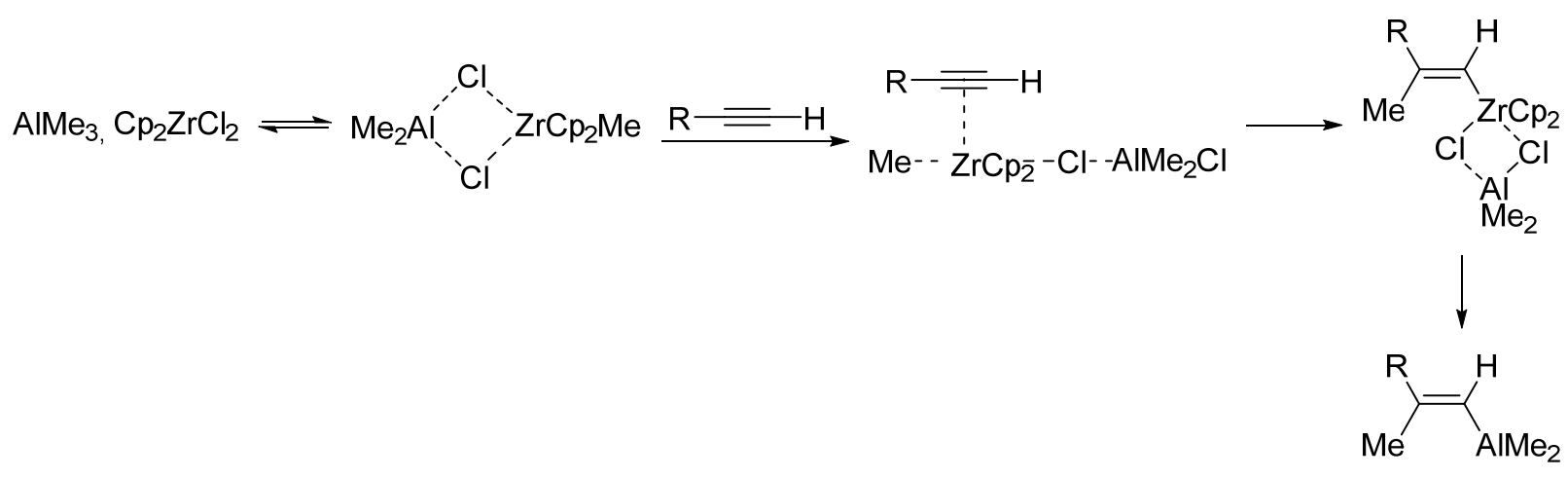

Scheme 22. Preparation of the alkenylalane compound for the Negishi reaction.

In this case, Negishi sought to optimize the coupling between the organozinc and the compound (E)-1-bromo-2-iodo-ethene while promoting the addition on the iodine atom as well as reducing the possibility of having a second coupling on the bromine atom. A search for the best solvent (Table 8 ) showed that a DMF/THF mixture $(2 / 1, v / v)$ was the best combination, as it favored the mono-coupling with iodine with only traces of compound 37. DMF had a very significant impact on the reaction because when the coupling was carried out in THF, the yield of compound 36 dropped to $20 \%$ without increasing the proportion of 37 . However, after $12 \mathrm{~h}$ of reaction time, they observed the formation of compound 37 with a yield of up to $10 \%$.

Table 8. Solvent optimization.

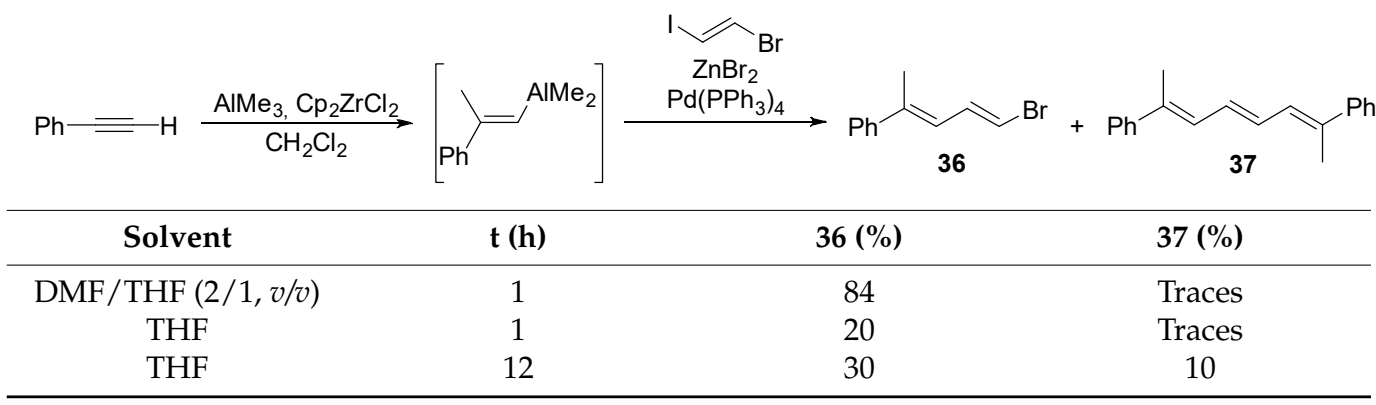

This process was used to synthesize vitamin A by reacting compound 38 under the conditions described above. The deprotection of the alkyne was then carried out to lead to conjugated compound 39 at a yield of $70 \%$ (Scheme 23). 
<smiles>C#C/C=C/C1=C(C)CCCC1(C)C</smiles>

38
1) $\mathrm{AlMe}_{3}, \mathrm{Cp}_{2} \mathrm{ZrCl}_{2}$ $\mathrm{DCM}$

2)<smiles>C=CCCCC</smiles>
$\mathrm{ZnCl}_{2}, \mathrm{Pd}_{2}(\mathrm{dba})_{3}$ TFP, THF, DMF, $23^{\circ} \mathrm{C}, 6 \mathrm{~h}$ 3) $\mathrm{K}_{2} \mathrm{CO}_{3}, \mathrm{MeOH}, 23^{\circ} \mathrm{C}, 3 \mathrm{~h}$

39<smiles>C#CCCCC1(C)CCCC(C)=C1/C=C/C(C)=C/C=C/C(C)=C/CO</smiles><smiles>C#CC=CC=C(C)C=CC1=C(C)CCCC1(C)C</smiles>

39

\section{Vitamin A}

Scheme 23. Synthesis of vitamin A via the Negishi reaction.

In 2004, Panek's group developed the total synthesis of Callystatin A through a Negishi coupling reaction [45]. Callystatin exhibits anti-tumor activity, and this antibiotic blocked some of the molecules involved in the cellular processes of proliferation, differentiation, development, and hormone action [46] To achieve this, alkyne 40 was brought into contact with the zirconium complex at room temperature. The advantage of using $\mathrm{Cp}_{2} \mathrm{ZrHCl}$, also called Schwartz's reagent, is that it adds a proton to the triple bond and not a methyl, which was the case previously [47]. The addition of zinc chloride in THF led to organozinc, which was immediately engaged in the Negishi coupling reaction with iodine compound 41 to generate compound 42 at a $51 \%$ yield. Various deprotection reactions then led to the target natural molecule (Scheme 24).

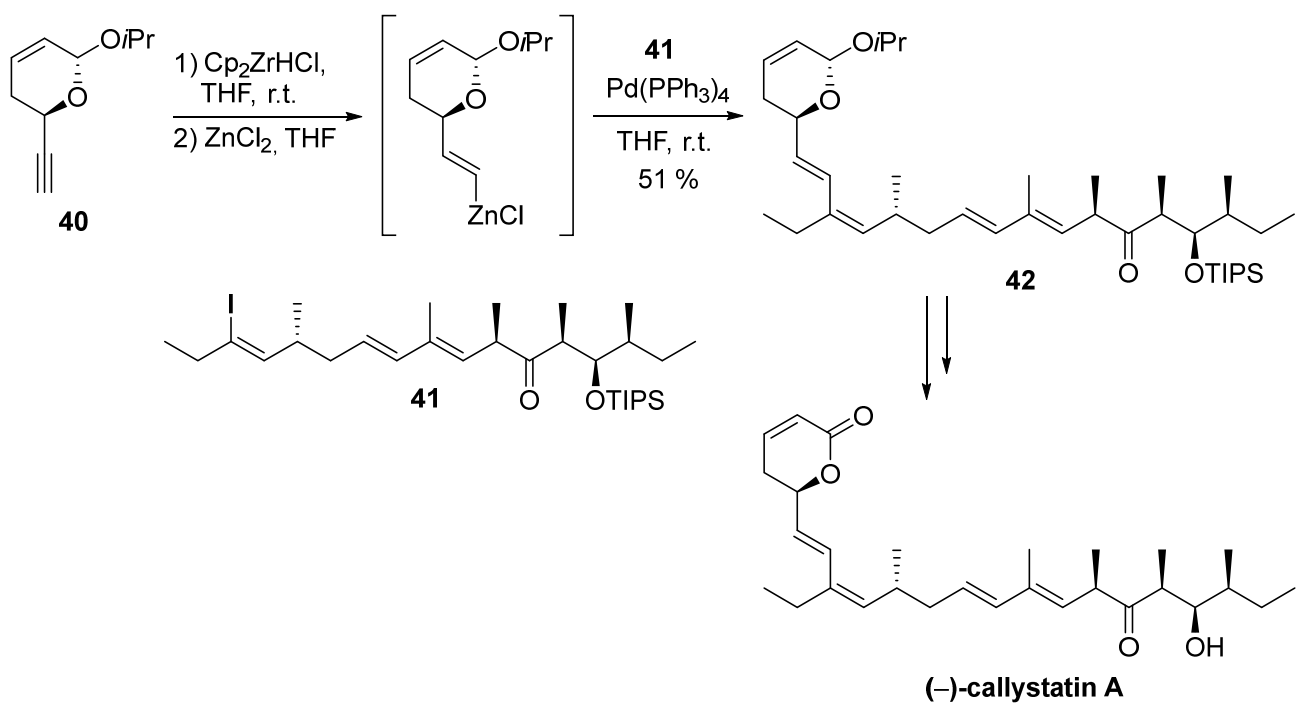

Scheme 24. Synthesis of callystatin A by Panek's group.

\subsubsection{The Mizoroki-Heck Reaction}

Heck-Mizoroki coupling is one of the most convenient methods for carbon-carbon double bond formation in small organic molecules. Here, we report the state-of-the art of conditions leading to conjugated diene compounds in general and an application of the synthesis to a natural molecule.

In 1971, Mizoroki's team published work to bound phenyl iodide and vinyl bromide in the presence of palladium and potassium carbonate [48]. In 1972, Heck's group described the same coupling but applied these conditions to various substrates [49]. This reaction, called the Heck-Mizoroki reaction (Scheme 25), is commonly used in organic synthesis, as the required building blocks are easy to access and are generally inexpensive. 


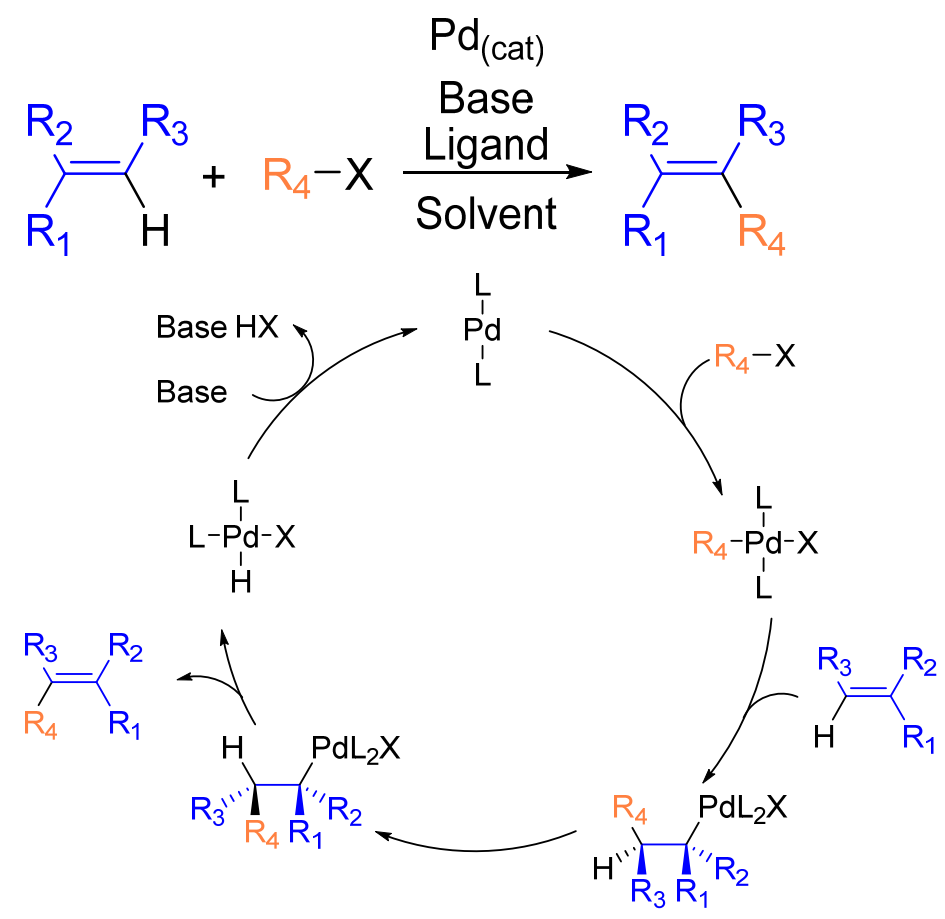

Scheme 25. General scheme and mechanism of the Heck-Mizoroki reaction.

The mechanism of this reaction is now well known [50]. To improve the environmental impact of its use, some studies have introduced improvements, for example the work by Hallberg's team in 2002, which describes a methodology for this coupling using microwaves as a thermal source [51]. The advantage of using this type of heating is that it reduces the reaction time considerably compared to conventional heating because microwaves heat the reaction media to the core. The coupling compounds that were obtained were all of configuration (E). The use of microwave irradiation did not modify the stereochemistry of the double bond since although isomerization occurred by the thermal effect, the products formed in these examples were thermodynamic products and not kinetic products. It should be noted that these conditions required high heating, with temperatures reaching up to $180^{\circ} \mathrm{C}$. This may not be tolerated by certain functions or even by complex molecules such as certain sugars, as it can lead to degradation and side products.

In 2012, the Lamaty team published coupling conditions in a solvent that had the particularity of being solid at room temperature: PEG2000 [52]. As before, the stereochemistry of the compounds was exclusively of group (E), and no isomerization was observed. In 2016, our team showed that Mizoroki-Heck coupling can also be conducted in an environmentally sound manner in PEG 400 [53]. In 2008, Han and his team developed a solvent-free Heck-Mizoroki coupling procedure with a catalyst supported by SBA-15 silica grafted with 1,1,3,3-tetramethylgaunidinium (TMG) [54]. Compounds were obtained in very good yields while only using a tiny amount of catalyst (0.001 mol\%). In 2017, Jagtap published an interesting review on the different conditions that can be used for the Heck coupling reaction, but it did not deal with the formation of conjugated dienes [55].Application of Mizoroki-Heck coupling to the synthesis of diene compounds.

In 2003, the Venturello team reported the coupling of conjugated diene compounds with aromatic iodine derivatives [56]. The yields obtained in these conditions were moderate, but the isolated compounds retained the stereochemistry $(\mathrm{E}, \mathrm{E})$ of the starting diene compound 43 (Table 9). 
Table 9. Heck coupling according to Venturello's group.

43
Entry

However, in these conditions, when the diene did not have an ester function but instead had an alkyl substituent such as a methyl 44 or a propyl 46 , the isomerization of the double bonds belonging the coupling product $(45,47)$ was observed (Scheme 26$)$.
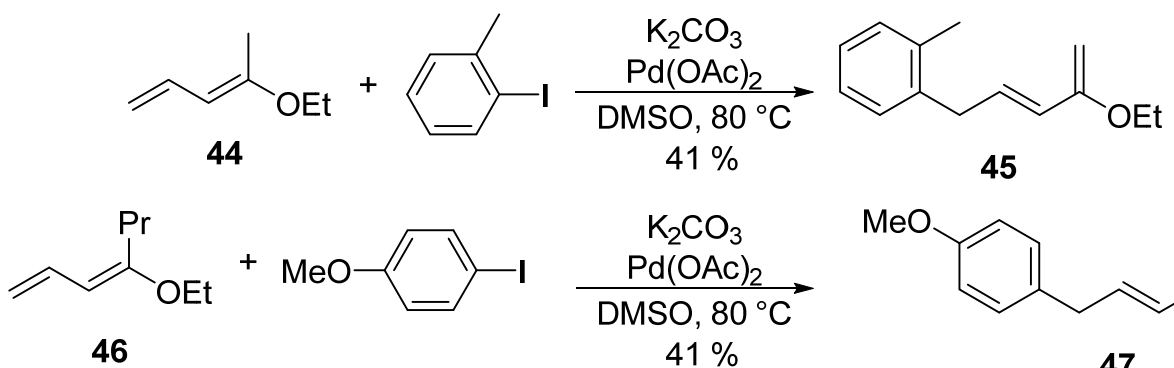<smiles>CC/C=C(\C=C\Cc1ccc(OC)cc1)OCC</smiles>

47<smiles>[R]C=C(/C=C/C[Al]CC)OCC</smiles>

Scheme 26. Mizoroki-Heck coupling with isomerization of double bonds and mechanism.

When this team used diene 48 in the previously described coupling conditions, isomerization was observed, and a cyclized compound was isolated. This intramolecular cyclization was the result of the addition of alcohol to the diene complexed with palladium. Finally, the catalyst was decomplexed from the alkene to lead to compound 49 (Scheme 27). The conformation of the compound obtained was exclusively (E).

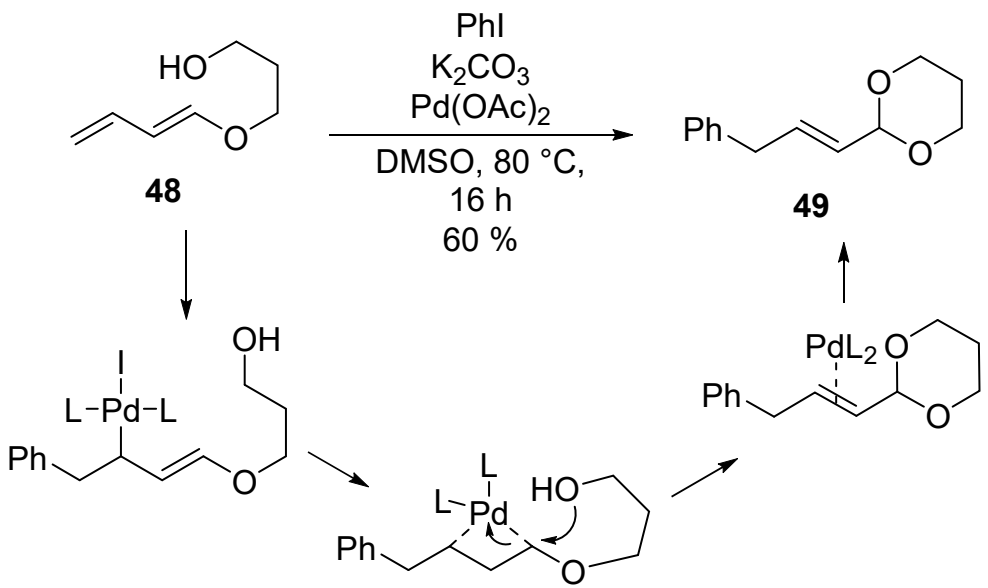

Scheme 27. Reaction mechanism of compound 49 synthesis. 
From this result, the Venturello team generalized their method using various iodine compounds and various substituted dienes. When the diene was not substituted, the yields ranged between $60 \%$ and $73 \%$ depending on the aromatics used, with one (E) configuration only (Table 10, entries 1 to 3 ). Substitution on the $3^{\prime}$ position of the diene used with a methyl group did indeed lead to the expected coupling compound, but a second isomer was observed (Table 10, entries 4 and 6). However, it was shown that when aryl is hindered in the ortho position, only compound (E) was isolated (entry 5). If the diene was substituted with a methyl at the $2^{\prime}$ position, then compound $(Z)$ was not observed in favor of compound (E) (Table 10, entry 7).

Table 10. Generalization of cyclizing Heck conditions.

Entry

The compounds that were thus isolated were of great synthetic interest because in the presence of an acid catalyst, it would be possible to regenerate an $\alpha, \beta$-unsaturated aldehyde by deprotection of the acetal function of the molecule.

In 2006, the same team developed conditions leading to dienes without any isomerization [57]. The base changed, but the most important variation was the replacement of DMSO by an ionic liquid, tetrabutylammonium bromide (Scheme 28). The compound obtained was a conjugated diene with an exclusive (E,E) 51 stereochemistry. 


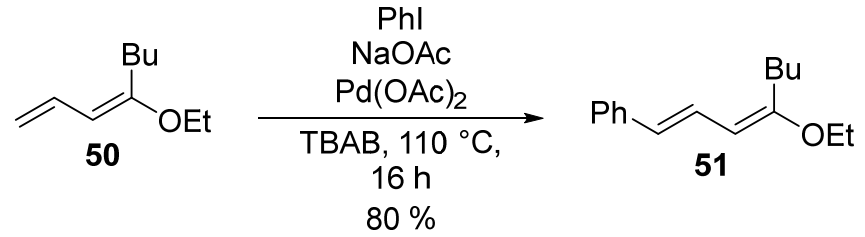

Scheme 28. Heck coupling in ionic solvent by Venturello.

In 2006 Skrydstrup's group developed a new methodology to generate conjugated diene compounds [58]. They started from tosylate compounds 52 instead of the usually used iodine compounds in the presence of $\mathrm{PdCl}_{2} \mathrm{cod}$ as the catalyst. The phosphine was present in the form of a salt and was prepared according to the method described by $\mathrm{Fu}$, with dicyclohexylmethylamine as a base in the medium [59]. These conditions required 1 equivalent of lithium chloride (50\%, Table 11 , entry 2$)$ and an increase in the reaction temperature to $100{ }^{\circ} \mathrm{C}$ to be efficient $(66 \%$, Table 11 , entry 3$)$.

Table 11. Optimization of the coupling conditions by Skrydstrup et al.

\begin{tabular}{|c|c|c|c|c|}
\hline & & $\begin{array}{r}\text { additi } \\
\mathrm{Cy}_{2} \mathrm{NM} \\
\mathrm{PdCl}_{2} \mathrm{C} \\
\mathrm{HBF}_{4} \mathrm{P}(t \mathrm{E} \\
\mathrm{DMF}\end{array}$ & 53 & \\
\hline Entry & Additive & $\begin{array}{c}\text { Temperature } \\
\left({ }^{\circ} \mathrm{C}\right)\end{array}$ & t (h) & Yield (\%) \\
\hline 1 & - & 85 & 24 & 5 \\
\hline 2 & $\mathrm{LiCl}$ & 85 & 24 & 50 \\
\hline 3 & $\mathrm{LiCl}$ & 100 & 24 & 66 \\
\hline
\end{tabular}

A generalization of the method was carried out. When styrene was used, coupling took place within $17 \mathrm{~h}$, with a yield of $96 \%$ (Table 12, entry 1 ). The result was even better with 4-vinyl-1,1'-biphenyl (Table 12, entry 2). The reaction was tolerant to many compounds, such as 4-vinylpyridine: the coupling compounds were obtained in a yield of $88 \%$ (Table 12 entry 3$)$.

Table 12. Generalization of the method by Skrydstrup's group.

Entry


Table 12. Cont.

\begin{tabular}{llll}
\hline Entry & $\mathbf{t ( h )}$ & Yield (\%) \\
\hline 5 & & 17 & 92 \\
\hline
\end{tabular}

In the context of applications for the synthesis of natural products, Dounay and Overmann reported an asymmetric intramolecular Heck reaction in the total synthesis of natural products [50], and other teams reported other total synthesis reactions [60-62]. To achieve our goal concerning natural products possessing a conjugated diene, in 2018, our team applied the Mizoroki-Heck reaction to synthetize abscisic acid (ABA) (Scheme 29) in an environmentally sound manner [63]. ABA is an important phytohormone [64-70] that has been reported to have interesting properties [71,72]. After having considered the different synthesis strategies reported in the literature [73-81], the Mizoroki-Heck reaction conditions were optimized with methyl (2Z)-3-iodobut-2-enoate and various allylic cyclohexenols and cyclohexanols.
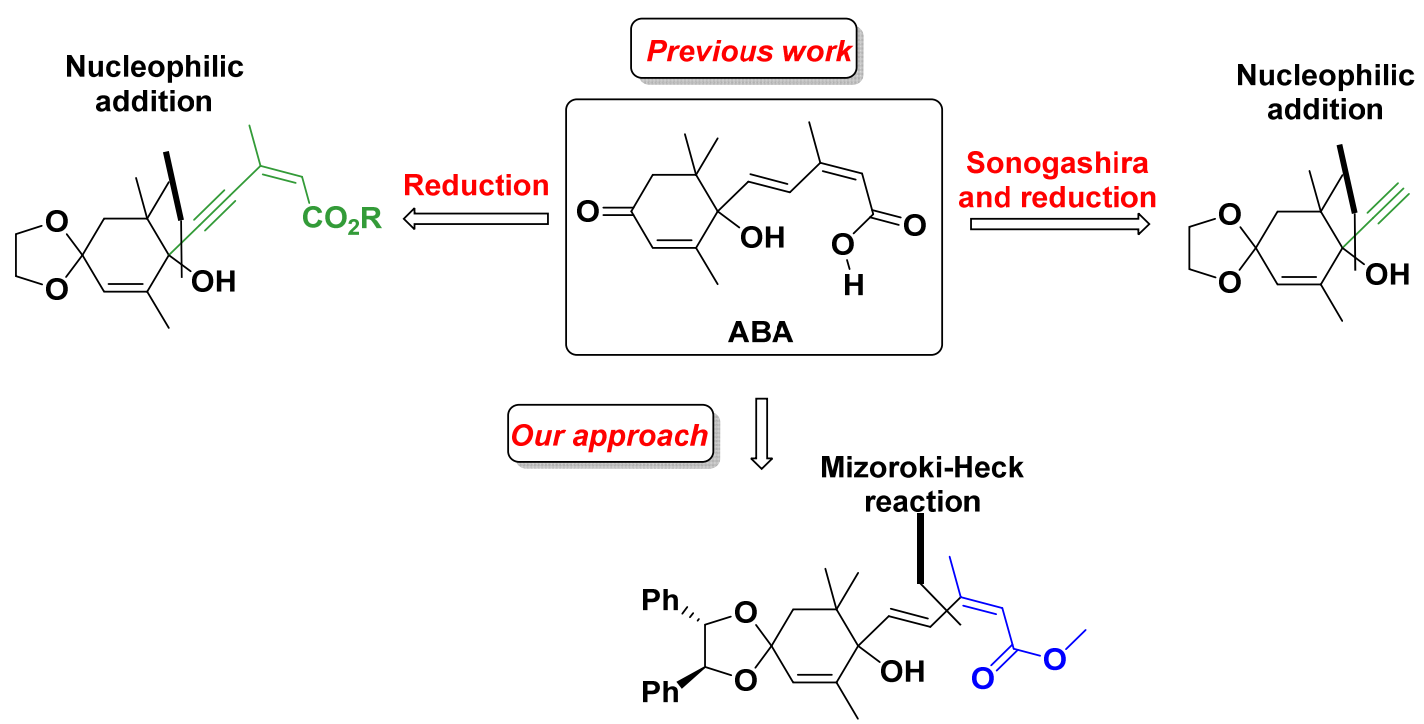

Scheme 29. Retrosynthetic approaches used by our team for the successful synthesis of ABA.

We succeeded in controlling the configuration of the double bonds, and no isomerization was observed. Our methodology was based on the association of simple terminal olefins with methyl (2Z)-3-iodobut-2-enoate in optimized solvent-free conditions in the presence of palladium acetate under air but without any ligand.

The expected (E/Z)-diene 57 was isolated in a $96 \%$ yield without racemization, and the $R / S$ ratio was maintained during the formation of the diene. After a final saponification followed by an acidic treatment, abscisic acid synthesis was carried out. The ABA enantiomerically enriched in its $S$ isomer was therefore synthetized in four steps, achieving a global yield of $54 \%$ (Scheme 30) [63]. 


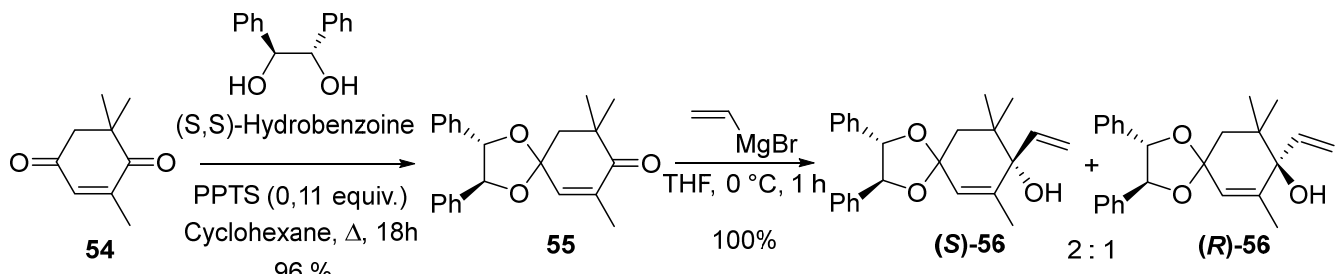

$96 \%$

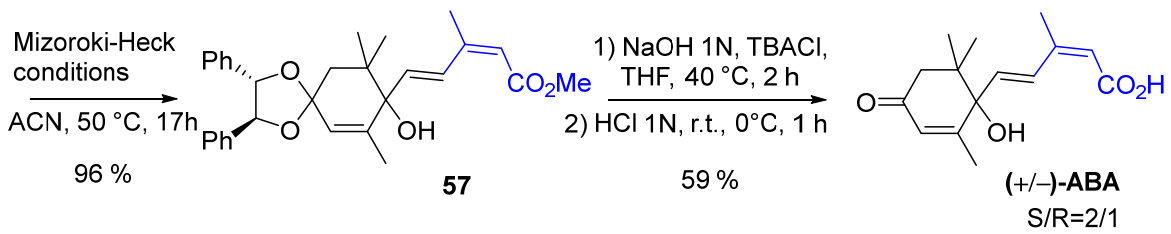

Scheme 30. ABA synthesis in four steps.

\section{Conclusions}

We have presented some reactions described since the 2000 s that have been conducted to obtain alkene compounds and, in particular, conjugated diene compounds. These reactions are very diverse and require, for the most part, a large number of precautions. The most important issue, however, is the toxicity of most of the catalysts required to accomplish the previously described couplings in the synthesis of these molecules of interest. That may be problematic for the production of these molecules on a large scale and should commit the scientific community to investing in all sustainable synthetic routes.

As diene moieties are often present in natural compounds, it is therefore necessary to develop or improve the conditions for these coupling reactions in an environmentally sound manner, as the use of chlorinated solvents, or even benzene, is still too widespread and should be optimized in favor of reactions that can be conducted without the use of solvent or with green solvents.

Author Contributions: Conceptualization and methodology, G.D. and S.B.-R.; investigation and data curation, G.D. and S.B.-R.; writing — original draft preparation, G.D. and S.B.-R.; writing-review and editing, S.B.-R.; supervision, project administration, and funding acquisition, S.B.-R. All authors have read and agreed to the published version of the manuscript.

Funding: From the Région Centre Val de Loire for the financing of G. Dumonteil.

Acknowledgments: We acknowledge the Région Centre for their financial support.

Conflicts of Interest: The authors declare no conflict of interest.

\section{References}

1. Hopf, H.; Maas, G. Synthesis and Transformation of Radialenes. In The Chemistry of Dienes and Polyenes; Rappoport, Z., Ed.; Wiley: Chichester, UK, 1997; Volume 1, ISBN 978-0-471-96512-1.

2. De Paolis, M.; Chataigner, I.; Maddaluno, J. Recent advances in stereoselective synthesis of 1,3-dienes. Top. Curr. Chem. 2012, 327, 87-146. [CrossRef]

3. Takeda, T. (Ed.) Modern Carbonyl Olefination: Methods and Applications; Wiley-VCH: Weinheim, Germany, 2004; ISBN 978-3-52760538-5.

4. Cahiez, G.; Moyeux, A.; Buendia, J.; Duplais, C. Manganese- or Iron-Catalyzed Homocoupling og Grignard Reagents Using Atmospheric Oxygen as an Oxydant. J. Am. Chem. Soc. 2007, 129, 13788-13789. [CrossRef] [PubMed]

5. Nguyen, S.T.; Johnson, L.K.; Grubbs, R.H.; Ziller, J.W. Ring-opening metathesis polymerization (ROMP) of norbornene by a Group VIII carbene complex in protic media. J. Am. Chem. Soc. 1992, 114, 3974-3975. [CrossRef]

6. Grubbs, R.H. Handbook of Metathesis; Grubbs, R.H., Ed.; Wiley-VCH: Weinheim, Germany, 2003; Volume 1, ISBN 978-3-527-30616-9.

7. Bazan, G.C.; Oskam, J.H.; Cho, H.N.; Park, L.Y.; Schrock, R.R. Living ring-opening metathesis polymerization of 2,3difunctionalized 7-oxanorbornenes and 7-oxanorbornadienes by Mo(CHCMe2R)(NC6H3-iso-Pr2-2,6)(O-Tert-Bu)2 and Mo(CHCMe2R)(NC6H3-iso-Pr2-2,6)(OCMe2CF3)2. J. Am. Chem. Soc. 1991, 113, 6899-6907. [CrossRef]

8. Schmidt, B.; Kunz, O. One-Flask Tethered Ring Closing Metathesis-Electrocyclic Ring Opening for the Highly Stereoselective Synthesis of Conjugated Z/E-Dienes. Eur. J. Org. Chem. 2012, 5, 1008-1018. [CrossRef] 
9. Gallenkamp, D.; Fürstner, A. Stereoselective Synthesis of E,Z-Configured 1,3-Dienes by Ring-Closing Metathesis. Application to the Total Synthesis of Lactimidocyn. J. Am. Chem. Soc. 2011, 133, 9232-9235. [CrossRef] [PubMed]

10. Schneider-Poetsch, T.; Ju, J.; Eyler, D.E.; Dang, Y.; Bhat, S.; Merrick, W.C.; Green, R.; Shen, B.; Liu, J.O. Inhibition of eukaryotic translation elongation by cycloheximide and lactimidomycin. Nat. Chem. Biol. 2010, 6, 209-217. [CrossRef]

11. Villar, H.; Frings, M.; Bolm, C. Ring closing enyne metathesis: A powerful tool for the synthesis of heterocycles. Chem. Soc. Rev. 2007, 36, 55-66. [CrossRef]

12. Desroy, N.; Robert-Peillard, F.; Toueg, J.; Duboc, R.; Hénaut, C.; Rager, M.-N.; Savignac, M.; Genêt, J.-P. An efficient route to 4/5/6 polycyclic beta-lactams. Eur. J. Org. Chem. 2004, 2004, 4840-4849. [CrossRef]

13. Saito, N.; Saito, K.; Shiro, M.; Sato, Y. Regio- and Stereoselective Synthesis of 2-Amino-1,3-diene Derivatives by RutheniumCatalyzed Coupling of Ynamides and Ethylene. Org. Lett. 2011, 13, 2718-2721. [CrossRef]

14. Zhang, J.; Ugrinov, A.; Zhang, Y.; Zhao, P. Exploring Bis(cyclometalated)Ruthenium(II) Complexes as Active Catalyst Precursors: Room Temperature Alkene-Alkyne Coupling for 1,3-Diene Synthesis. Angew. Chem. Int. Ed. 2014, 53, 8437-8440. [CrossRef] [PubMed]

15. Kim, C.H.; An, H.J.; Shin, W.K.; Yu, W.; Woo, S.K.; Jung, S.K.; Lee, E. Total Synthesis of (-)-Amphidinolide E. Angew. Chem. Int. Ed. 2006, 45, 8019-8021. [CrossRef]

16. Mannathan, S.; Cheng, C.-H. Cobalt-catalyzed regio- and stereoselective intermolecular enyne coupling: An efficient route to 1,3-diene derivatives. Chem. Commun. 2010, 46, 1923-1925. [CrossRef]

17. Stille, J.K. Palladium catalyzed coupling of organotin reagents with organic electrophiles. Pure Appl. Chem. 1985, 57, 1771-1780. [CrossRef]

18. Stille, J.K. The Palladium-Catalyzed Cross-Coupling Reactions of Organotin Reagents with Organic Electrophiles. Angew. Chem. Int. Ed. Engl. 1986, 25, 508-524. [CrossRef]

19. Farina, V. New perspectives in the cross-coupling reactions of organostannanes. Pure Appl. Chem. 1996, 68, 73-78. [CrossRef]

20. Pattenden, G.; Sinclair, D.J. The intramolecular Stille reaction in some target natural product synthesis. J. Organomet. Chem. 2002, 653, 261-268. [CrossRef]

21. Farina, V.; Krishnamurthy, V.; Scott, W.J. The Stille Reaction. Org. React. 1997, 50, 1. [CrossRef]

22. Brooke, D.G.; Morris, J.C. Total synthesis of hydroxystrobilurin A via Stille coupling. Tetrahedron Lett. 2008, 49, $2414-2417$. [CrossRef]

23. Engler, M.; Anke, T.; Klostermeyer, D.; Steglich, W. Hydroxystrobilurin A, a new Antifungal E- $\beta$-methoxyacrylate from a Pterula species. J. Antibiotics 1995, 48, 884-888. [CrossRef]

24. Smith, A.B.; Duffey, M.O.; Basu, K.; Walsh, S.P.; Suennemann, H.W.; Frohn, M. Total synthesis of the assigned structures of Lituarines B and C. J. Am. Chem. Soc. 2008, 130, 422-423. [CrossRef]

25. Miyaura, N.; Suzuki, A. Palladium-Catalyzed Cross-Coupling Reactions of Organoboron Compounds. Chem. Rev. 1995, 95, 2457-2483. [CrossRef]

26. Stanforth, S.P. Catalytic cross-coupling reactions in biaryl synthesis. Tetrahedron 1998, 54, 263-303. [CrossRef]

27. Suzuki, A. Recent advances in the cross-coupling reactions of organoboron derivatives with organic electrophiles 1995-1998. J. Organomet. Chem. 1999, 576, 147-168. [CrossRef]

28. Miyaura, N.; Yamada, K.; Suzuki, A. A new stereospecific cross-coupling by the palladium-catalyzed reaction of 1-alkenylboranes with 1-alkenyl or 1-alkynyl halides. Tetrahedron Lett. 1979, 36, 3437-3440. [CrossRef]

29. Muir, J.C.; Pattenden, G.; Ye, T. Total synthesis of (+)-curacin A, a novel antimitotic metabolite from a cyanobacterium. J. Chem. Soc. Perkin Trans. 1 2002, 20, 2243-2250. [CrossRef]

30. Chang, Z.; Sitachitta, N.; Rossi, J.V.; Roberts, M.A.; Flatt, P.M.; Jia, J.; Sherman, D.H.; Gerwick, W.H. Biosynthetic Pathway and Gene Cluster Analysis of Curacin A, an Antitubulin Natural Product from the Tropical Marine Cyanobacterium Lyngbya majuscula. J. Nat. Prod. 2004, 67, 1356-1367. [CrossRef] [PubMed]

31. Gu, L.; Geders, T.W.; Wang, B.; Gerwick, W.H.; Håkansson, K.; Smith, J.L.; Sherman, D.H. GNAT-Like Strategy for Polyketide Chain Initiation. Science 2007, 318, 970-974. [CrossRef]

32. Verdier-Pinard, P.; Lai, J.-Y.; Yoo, H.-D.; Yu, J.; Marquez, B.; Nagle, D.G.; Nambu, M.; White, J.D.; Falck, J.R.; Gerwick, W.H.; et al. Structure-Activity Analysis of the Interaction of Curacin A, the Potent Colchicine Site Antimitotic Agent, with Tubulin and Effects of Analogs on the Growth of MCF-7 Breast Cancer Cells. Mol. Pharmacol. 1998, 53, 62-76. [CrossRef] [PubMed]

33. Blokhin, A.V.; Yoo, H.D.; Geralds, R.S.; Nagle, D.G.; Gerwick, W.H.; Hamel, E. Characterization of the interaction of the marine cyanobacterial natural product curacin A with the colchicine site of tubulin and initial structure-activity studies with analogues. Mol. Pharmacol. 1995, 48, 523-531.

34. Molander, G.A.; Dehmel, F. Formal total synthesis of oximidine II via a Suzuki-type cross-coupling macrocyclization employing potassium organotrifluoroborates. J. Am. Chem. Soc. 2004, 126, 10313-10318. [CrossRef]

35. Wang, X.; Porco, J.A., Jr. Total synthesis of the salicylate Enamide Macrolide Oximidine II. J. Am. Chem. Soc. 2003, 125, 6040. [CrossRef] [PubMed]

36. Corriu, R.J.P.; Masse, J.P. Activation of Grignard reagents by transition-metal complexes. A new and simple synthesis of trans-stilbenes and polyphenyls. J. Chem. Soc. Chem. Commun. 1972, 3, 144a. [CrossRef]

37. Kiso, Y.; Yamamoto, K.; Talmao, K.; Kumada, M. Asymmetric homogeneous hydrosilylation with chiral phosphine-palladium complexes. J. Am. Chem. Soc. 1972, 94, 4373-4374. [CrossRef] 
38. Liu, P.; Jacobsen, E.N. Total Synthesis of (+)-Ambruticin. J. Am. Chem. Soc. 2001, 123, 10772. [CrossRef] [PubMed]

39. Ringel, S.M.; Greenough, R.C.; Roemer, S.; Connor, D.; Gutt, A.L.; Blair, B.; Kanter, G.; von Strandtmann, M. Ambruticin (W7783), a new antifungal antibiotic. J. Antibiot. 1977, 30, 371. [CrossRef]

40. King, A.O.; Okukado, N.; Negishi, E. Highly general stereo-, regio-, and chemo-selective synthesis of terminal and internal conjugated enynes by the Pd-catalysed reaction of alkynylzinc reagents with alkenyl halides. J. Chem. Soc. Chem. Commun. 1977, 19, 683-684. [CrossRef]

41. Negishi, E.; Okukado, N.; King, A.O.; Van Horn, D.E.; Spiegel, B.I. Selective carbon-carbon bond formation via transition metal catalysts. 9. Double metal catalysis in the cross-coupling reaction and its application to the stereo- and regioselective synthesis of trisubstituted olefins. J. Am. Chem. Soc. 1978, 100, 2254-2256. [CrossRef]

42. Negishi, E.; Hu, Q.; Wang, Z.; Yin, N. The Chemistry of Organozinc Compounds; Rappoport, Z., Marek, I., Eds.; John Wiley \& Sons, Ltd.: Chichester, UK, 2006; Chapter 11; p. 453. ISBN 9780470093399.

43. Donohoe, T.J.; Ironmonger, A.; Kershaw, N.M. Synthesis of (-)-(Z)-Deoxypukalide. Angew. Chem. Int. Ed. 2008, 47, 7314-7316. [CrossRef]

44. Zeng, F.; Negishi, E. A novel, Selective, and Efficient route to Carotenoids and related Natural Products via Zr-Catalyzed Carboalumination and Pd- and Zn-Catalyzed Cross Coupling. Org. Lett. 2001, 3, 719-722. [CrossRef]

45. Langille, N.F.; Panek, J.S. Total synthesis of (-)-Callystatin A. Org. Lett. 2004, 6, 3203-3206. [CrossRef]

46. Kobayashi, M.; Higuchi, K.; Murakami, N.; Tajima, H.; Aoki, S. Callystatin A, a potent cytotoxic polyketide from the marine sponge, Callyspongia truncata. Tetrahedron Lett. 1997, 38, 2859-2862. [CrossRef]

47. Schwartz, J.; Labinger, J.A. Hydrozirconation: A new transition metal reagent for organic synthesis. Angew. Chem. Int. Ed. 1976, 15, 333-340. [CrossRef]

48. Mizoroki, T.; Mori, K.; Ozaki, A. Arylation of Olefin with Aryl Iodide Catalyzed by Palladium. Bull. Chem. Soc. Jpn. 1971, 44, 581. [CrossRef]

49. Heck, R.F.; Nolley, J.P. Palladium-catalyzed vinylic hydrogen substitution reactions with aryl, benzyl, and styryl halides. J. Org. Chem. 1972, 37, 2320-2322. [CrossRef]

50. Dounay, A.B.; Overman, L.E. The asymmetric intramolecular Heck reaction in natural product total synthesis. Chem. Rev. 2003, 103, 2945-2964. [CrossRef]

51. Vallin, K.S.A.; Emilsson, P.; Larhed, M.; Hallberg, A. High-speed Heck reactions in ionic liquid with controlled microwave heating J. Org. Chem. 2002, 67, 6243-6246. [CrossRef]

52. Declerck, V.; Colacino, E.; Bantreil, X.; Martinez, J.; Lamaty, F. Poly(ethylene glycol) as reaction medium for mild Mizoroki-Heck reaction in a ball-mill. Chem. Commun. 2012, 48, 11778-11780. [CrossRef]

53. Dumonteil, G.; Hiebel, M.-A.; Scherrmann, M.-C.; Berteina-Raboin, S. Iodine-catalyzed formation of substituted 2aminobenzothiazole derivatives in PEG400. RSC Adv. 2016, 6, 73517-73521. [CrossRef]

54. Ma, X.; Zhou, Y.; Zhang, J.; Zhu, A.; Jiang, T.; Han, B. Solvent-free Heck reaction catalyzed by a recyclable Pd catalyst supported on SBA-15 via an ionic liquid. Green Chem. 2008, 10, 59-66. [CrossRef]

55. Jagtap, S. Heck reaction-State of the art. Catalysts 2017, 7, 267. [CrossRef]

56. Deagostino, A.; Prandi, C.; Venturello, P. Palladium-Catalyzed Heck Reaction on 1-Alkoxy-1,3-dienes: A Regioselective $\gamma$ Arylation of a $\alpha, \beta$-Unsaturated Carbonyl Compounds. Org. Lett. 2003, 5, 3815-3817. [CrossRef]

57. Beccaria, L.; Deagostino, A.; Prandi, C.; Zavattaro, C.; Venturello, P. Heck Reaction on 1-Alkoxy-1,3-dienes in Ionic Liquids: A Superior Medium for the Regioselective Arylation of the Conjugated Dienic System. Synlett 2006, 18, 2989-2992. [CrossRef]

58. Hanse, A.L.; Ebran, J.-P.; Ahlquist, M.; Norrby, P.-O.; Skrydstrup, T. Heck Coupling with Nonactivated Alkenyl Tosylates and Phosphates. Examples of Effective 1,2-Migrations of the Alkenyl Palladium(II) Intermediates. Angew. Chem. Int. Ed. 2006, 45, 3349-3353. [CrossRef] [PubMed]

59. Netherton, M.R.; Fu, G.C. Air-Stable Trialkylphosphonium Salts: Simple, Practical, and Versatile Replacements for Air-Sensitive Trialkylphosphines. Applications in Stoichiometric and Catalytic Processes. Org. Lett. 2001, 3, 4295-4298. [CrossRef] [PubMed]

60. O'Nei, G.W.; Phillips, A.J. Total Synthesis of (-)-Dictyostatin. J. Am. Chem. Soc. 2006, 128, 5340-5341. [CrossRef]

61. Eto, K.; Yoshino, M.; Takahashi, K.; Ishihara, J.; Hatakeyama, S. Total Synthesis of Oxazolomycin A. Org. Lett. 2011, 13, 5398-5401. [CrossRef]

62. Souris, C.; Frébault, F.; Patel, A.; Audisio, D.; Houk, K.N.; Maulide, N. Stereoselective Synthesis of Dienyl-Carboxylate Building Blocks: Formal Synthesis of Inthomycin C. Org. Lett. 2013, 15, 3242-3245. [CrossRef]

63. Dumonteil, G.; Hiebel, M.-A.; Berteina-Raboin, S. Solvent-Free Mizoroki-Heck Reaction Applied to the Synthesis of Abscisic Acid and Some Derivatives. Catalysts 2018, 8, 115. [CrossRef]

64. Addicott, F.T.; Carns, H.R. Abscisic Acids; Addicott, F.T., Ed.; Praeger: New York, NY, USA, 1983; Chapter 1.

65. Finkelstein, R.F.; Tenbarge, K.M.; Shumway, J.E.; Crunch, M.L. Role of ABA in Maturation of Rapeseed Embryos. Plant Physiol. 1985, 78, 630-636. [CrossRef]

66. Léon-Kloosterziel, K.M.; Van de Bunt, G.A.; Zeevaart, J.A.D.; Koornneef, M. Arabidopsis Mutants with a Reduced Seed Dormancy. Plant Physiol. 1996, 110, 233-240. [CrossRef]

67. Shinozaki, K.; Yamaguchi-Shinozaki, K. Molecular responses to dehydration and low temperature: Differences and cross-talk between two stress signaling pathways. Curr. Opin. Plant Biol. 2000, 3, 217-223. [CrossRef]

68. Himmelbach, A.; Yang, Y.; Grill, E. Relay and control of abscisic acid signaling. Curr. Opin. Plant Biol. 2003, 6, 470-479. [CrossRef] 
69. Nambara, E.; Marion-Poll, A. Abscisic acid biosynthesis and catabolism. Annu. Rev. Plant Biol. 2005, 56, 165-186. [CrossRef] [PubMed]

70. Todoroki, Y.; Narita, K.; Muramatsu, T.; Shimamura, H.; Ohnishi, T.; Mizutani, M.; Ueno, K.; Hirai, N. Synthesis and biological activity of amino acid conjugates of abscisic acid. Bioorg. Med. Chem. 2011, 19, 1743-1750. [CrossRef]

71. Guri, A.J.; Hontecillas, R.; Si, H.; Liu, D.; Bassaganya-Riera, J. Dietary abscisic acid ameliorates glucose tolerance and obesityrelated inflammation in $\mathrm{db} / \mathrm{db}$ mice fed high-fat diets. Clin. Nutr. 2007, 26, 107-116. [CrossRef]

72. Bellotti, M.; Salis, A.; Grozio, A.; Damonte, G.; Vigliarolo, T.; Galatini, A.; Zocchi, E.; Benatti, U.; Millo, E. Synthesis, structural characterization and effect on human granulocyte intracellular cAMP levels of abscisic acid analogs. Bioorg. Med. Chem. 2015, 23, 22-32. [CrossRef]

73. Roberts, D.L.; Heckmann, R.A.; Hege, B.P.; Bellin, S.A. Synthesis of (RS)-abscisic acid. J. Org. Chem. 1968, 33, 3566-3569. [CrossRef]

74. Constantino, M.G.; Losco, P. A novel synthesis of ( \pm )-abscisic acid. J. Org. Chem. 1989, 54, 681-683. [CrossRef]

75. Cornforth, J.; Hawes, J.E.; Mallaby, R. A Stereospecific Synthesis of (土)-Abscisic Acid. Aust. J. Chem. 1992, 45, 179-185. [CrossRef]

76. Mayer, H.J.; Rigassi, N.; Schwieter, U.; Weedon, B.C.L. Synthesis of Abscisic Acid. Helv. Chim. Acta 1976, 59, 1424-1427. [CrossRef]

77. Kienzle, F.; Mayer, H.; Minder, R.E.; Thommen, H. Synthese von optisch aktiven, natürlichen Carotinoiden und strukturell verwandten Verbindungen. III. Synthese von (+)-Abscisinsäure, (-)-Xanthoxin, (-)-Loliolid, (-)-Actinidiolid und (-)-Dihydroactinidiolid. Helv. Chim. Acta 1978, 61, 2616-2627. [CrossRef]

78. Constantino, M.G.; Donate, P.M.; Petragnani, N. An efficient synthesis of ( \pm )-abscisic acid. J. Org. Chem. 1986, 51, 253-254. [CrossRef]

79. Rose, P.A.; Abrams, S.R.; Shaw, A.C. Synthesis of chiral acetylenic analogs of the plant hormone abscisic acid. Tetrahedron Asymmetry 1992, 3, 443-450. [CrossRef]

80. Hanson, J.R.; Uyanik, C. An efficient synthesis of the plant hormone abscisic acid. J. Chem. Res. 2003, 7, 426-427. [CrossRef]

81. Smith, T.R.; Clark, A.J.; Clarkson, G.J.; Taylor, P.C.; Marsh, A. Concise enantioselective synthesis of abscisic acid and a new analogue. Org. Biomol. Chem. 2006, 4, 4186-4192. [CrossRef] [PubMed] 